\title{
NONDESTRUCTIVE-EVALUATION NEEDS FOR COAL LIQUEFACTION
}

by
D. S. Kupperman

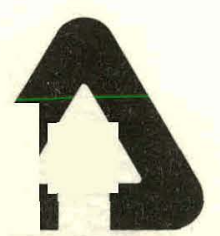

U Of C-AUA-USERDA

ARGONNE NATIONAL LABORATORY, ARGONNE, ILLINOIS

Prepared for the DIVISION OF MATERIALS

AND EXPLORATORY RESEARCH/FOSSIL ENERGY,

MSTER

U. S. ENERGY RESEARCH AND DEVELOPMENT ADMINISTRATION under Contract W-31-109-Eng-38 


\section{DISCLAIMER}

This report was prepared as an account of work sponsored by an agency of the United States Government. Neither the United States Government nor any agency Thereof, nor any of their employees, makes any warranty, express or implied, or assumes any legal liability or responsibility for the accuracy, completeness, or usefulness of any information, apparatus, product, or process disclosed, or represents that its use would not infringe privately owned rights. Reference herein to any specific commercial product, process, or service by trade name, trademark, manufacturer, or otherwise does not necessarily constitute or imply its endorsement, recommendation, or favoring by the United States Government or any agency thereof. The views and opinions of authors expressed herein do not necessarily state or reflect those of the United States Government or any agency thereof. 


\section{DISCLAIMER}

Portions of this document may be illegible in electronic image products. Images are produced from the best available original document. 
The facilities of Argonne National Laboratory are owned by the United States Government. Under the terms of a contract (W-31-109-Eng-38) between the U. S. Energy Research and Development Administration, Argonne Universities Association and The University of Chicago, the University employs the staff and operates the Laboratory in accordance with policies and programs formulated, approved and reviewed by the Association.

\section{MEMBERS OF ARGONNE UNIVERSITIES ASSOCIATION}

The University of Arizona Carnegie-Mellon University Case Western Reserve University The University of Chicago University of Cincinnati Illinois Institute of Technology University of Illinois Indiana University Iowa State University The University of Iowa
Kansas State University The University of Kansas Loyola University Marquette University Michigan State University The University of Michigan University of Minnesota University of Missuuri Northwestern University University of Notre Dame
The Ohio State University Ohio University The Pennsylvania State University Purdue University Saint Louis University Southern Illinois University The University of Texas at Austin Washington University Wayne State University The University of Wisconsin

\section{NOTICE}

This report was prepared as an account of work sponsored by the United States Government. Neither the United States nur the United States Energy Research and Development Administration, nor any of their employees, nor any of their contractors, subcontractors, or their employees, makes any warranty, express or implied, or assumes any legal liability or responsibility for the accuracy, completeness or usefulncss of any information, apparatus, product us process disclosed, or represents that its use would not infringe privately-owned rights. Mention of commercial products, their manufacturers, or their suppliers in this publication does not imply or connote approval or disapproval of the product by Argonne National Laboratory or the U. S. Energy Research and Development Administration.

Printed in the United States of America Available from

National Technical Information Service

U. S. Department of Commerce

5285 Port Royal Road

Springfield, Virginia 22161

Price: Printed Copy $\$ 3.00$ 
Distribution Category:

Coal Conversion and UtilizationLiquefaction (UC-90d)

ANL-77-6I

\section{ARGONNE NATIONAL LABORATORY 9700 South Cass Avenue \\ Argonne, Illinois 60439}

\section{NONDESTRUCTIVE-EVALUATION NEEDS \\ FOR COAL LIQUEFACTION}

\section{by}

D. S. Kupperman

Materials Science Division

September 1977

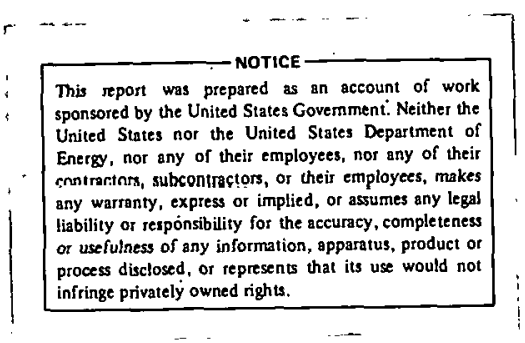




\section{THIS PAGE}

\section{WAS INTENTIONALLY \\ LEFT BLANK}




\section{TABLE OF CONTEN̦TS}

$\underline{\text { Page }}$

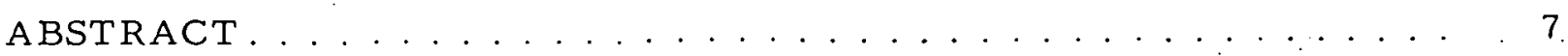

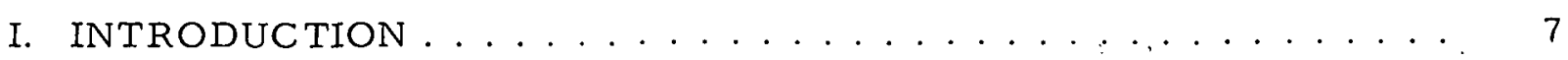

A. Survey Objectives and Procedures. ............. 8

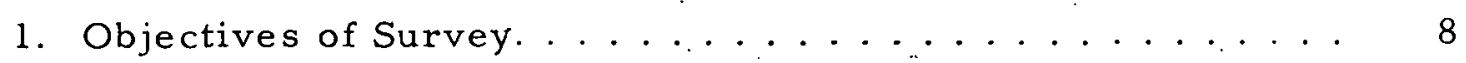

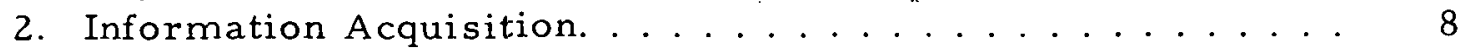

B. Process Descriptions .................... 8

1. COED (Char Oil Energy Development)............ 9

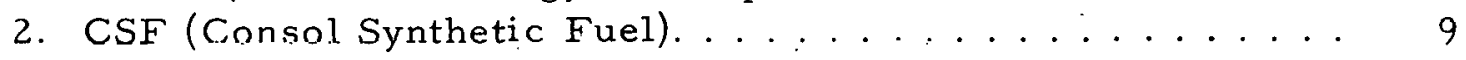

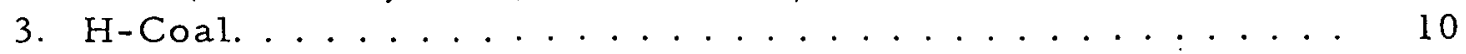

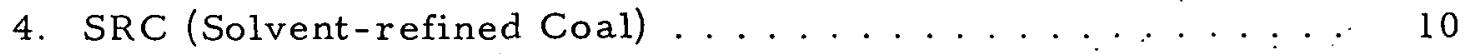

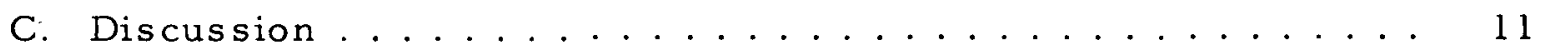

II. POTENTIAL AREAS FOR APPLICATION OF NONDESTRUCTIVEEVALUATION TECHNIQUES . . . . . . . . . . . . . . 11

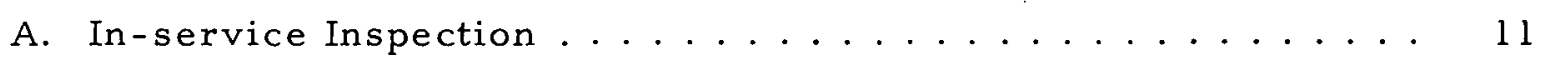

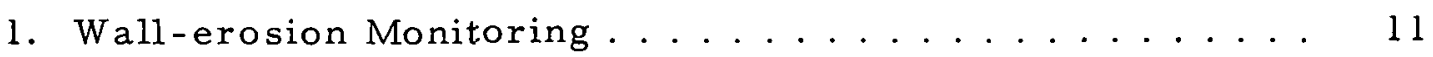

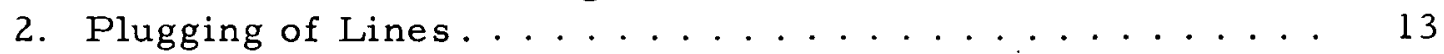

3. Hot-spot Monitoring ..................... 14

4. Letdown Valves...................... . . 14

5. Detection of Flammable Leaks ............. 15

6. Bearing and Pump Wear ................ 15

7. Nondestructive Evaluation for Microstructural Changes . 16

8. Fluidized-bed Level Detection .............. 17

9. Heat Exchangers and Heater Coils. . . . . . . . . . 17

10. Detection of Stress-corrosion Cracks ............ 18

11. Relation of Quantitative NDE to Fracture-mechanics

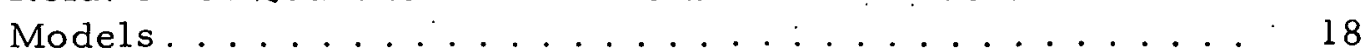

12. Establishment of On-line Test Facilities for Measuring

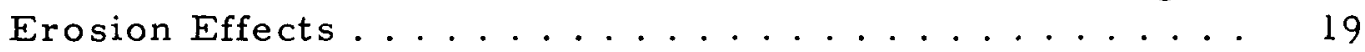

B. Preservice Inspection. . . . . . . . . . . . . . 19

1. Improved Inspection of Heavy Sections. . . . . . . . . . . 19

2. Improved Inspection of Welds. . . . . . . . . . . 21

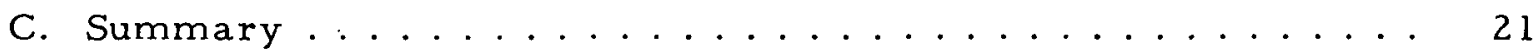




\section{TABLE OF CONTENTS}

$\underline{\text { Page }}$

\section{APPENDIXES}

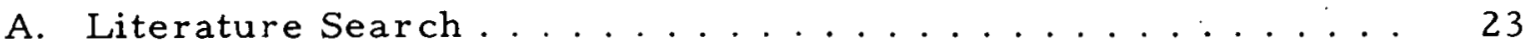

1. Literature-search Procedures .............. 23

2. Summary of Literature Review . . . . . . . . . . . . . . 23

3. Review of Selected Papers ................ 24

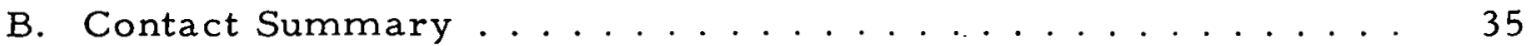

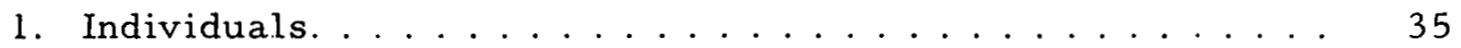

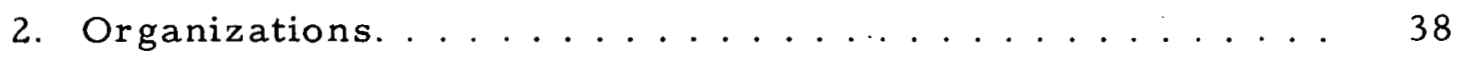

3. Areas ot Hotential INDE Application ........... 42

ACKNOWLEDGMENTS . . . . . . . . . . . . . . . . . . . 43

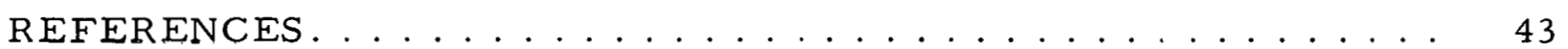




\section{LIST OF FIGURES}

No.

1. SRC Plant, Tacoma (Ft. Lewis), Washington............

2. Welded Pipe Where Erosion of Pipe Is a Serious Problem in

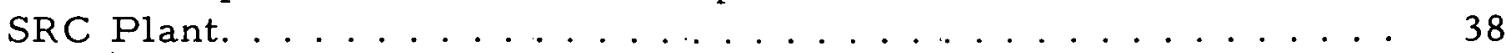

3. Carbon-steel Discharge Pipe, Showing Erosion at SRC Plant. . . 39

4. Discharge Pipe of a Filter Feed-surge Recirculation Pump, Showing Erosion at SRC Plant ................ 39

5. Preheater at SRC Plant, Tacoma (Ft. Lewis), Washington..... 39

6. Preheater Heating Coil at SRC Plant. . . . . . . . . . 39

7. Slurry Pump at SRC Plant. . . . . . . . . . . . . 40

8. Letdown Valve at SRC Plant................. 41

9. Dissolver Vessel at SRC Plant................. 41

10. Fractionation Columns at SRC Plant .............. 41

11. HRI Process Development Unit, Trenton, New Jersey. ...... 4 41

TABLE

No. $\quad \underline{\text { Title }}$

$\underline{\text { Page }}$

I. Potential Areas of Application for NDE Techniques in Coal

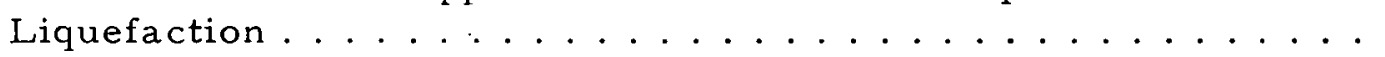


THIS PAGE

WAS INTENTIONALLY

LEFT BLANK 


\title{
NONDESTRUCTIVE-EVALUATION NEEDS FOR COAL LIQUEFACTION
}

by

D. S. Kupperman

\begin{abstract}
Nondéstructive-evaluation (NDE) needs for coal liquefaction have been identified by acquiring information from site visits, a literature review, and discussions with government personnel. Nondestructive evaluation has been highly rated in importance as a way to help alleviate problems in coalconversion systems. The primary problems are associated with highly erosive and corrosive slurries being transferred throughout the coal-conversion process. Applicable NDE techniques for both preservice and in-service inspection include high-temperature ultrasonics, acoustic emission, radiography, acoustic holography, and ultrasonic spectroscopy.
\end{abstract}

\section{INTRODUCTION}

The nationwide shortage of energy, combined with the abundance of coal reserves, makes the production of synthetic fuels from coal an important process to help meet the nation's demands for clean energy. As a result of this need and the potential for producing synthetic fuels, the Office of Fossil Energy of the U. S. Energy Research and Development Administration (ERDA) is carrying out several programs to make the necessary technology available to industry so that synthetic fuels can be produced economically. Coal liquefaction, however, is not a new technology. The process was introduced as early as the 1920's. During World War II, Germany produced liquid hydrocarbons by the high-pressure hydrogenation of coal. In the 1950's, the United States worked on the development of the liquefaction process, but at that time the process was not economical. With the current shortages of petroleum and gas, and vast coal reserves, interest has again peaked for coal-liquefaction development.

The advantage of coal liquefaction is that a wide range of liquid products (fuel oil, gasoline, jet fuel, diesel, etc.) can be produced from coal. As a result, from the 1960 's and on, several pilot plants have been built and operated with greatly varying degrees of success. At present, ERDA is involved in the development of several conversion processes at different stages of development. 
A. Survey Objectives and Procedures

\section{Objectives of Survey}

The objectives of the survey program to establish the nondestructiveevaluation (NDE) needs for coal liquefaction are as follows:

a. Compile a list of problem areas (actual or anticipated). in coal-liquefaction pilot plants presently operating or planned that should be addressed by NDE.

b. Make recommendations relative to which NDE methods may be useful in contributing to the solution of anticipated and existing problems.

c. Indicate areas for which development of NDE methods may be required in terms of techniques (e.g., acoustic and electromagnetic) and environments (e.g., temperature, pressure, and materials).

\section{Information Acquisition}

Nondestructive-evaluation needs for coal liquefaction have been assessed by analyzing information compiled from three sources: (a) relevant and available literature on coal-liquefaction plants, (b) knowledgeable personnel from government offices and industrial facilities, and (c) site visits to existing pilot plants.

The literature search was carried out via a computer search using various retrieval systems and a manual search of several abstract sources (see Appendix A, part 1). Hersonal communications have led to the accumulation of additional relevant papers and manuscripts.

To obtain current information on coal-liquefaction problem areas in which nondestructive evaluation may contribute to solutions, contacts were made with field and administrative personnel from industry and government organizations. Site visits were also made when possible to pilot-plant facilities to help assess the potential for NDE. Details of these contacts are discussed in Appendix B.

Information has been accumulated primarily on ERDA-sponsored facilities (SRC, H-Coal, CSF, CRESAP, and COED).

\section{B. Process Descriptions}

ERDA is involved with four pilot plants built or in planning stages:

1. Char Oil Energy Development (COED) Pilot Plant, FMC Corporation, Princeton, New Jersey.

2. Solvent-refined Coal (SRC) Plant, Pittsburg and Midway Coal Mining Company, Tacoma (Ft. Lewis), Washington. 
3. H-Coal Pilot Plant, Hydrocarbon Research Inc., Catlettsburg, Kentucky (and H-Coal Process Development Unit, Trenton, New Jersey).

4. Consul Synthetic Fuel (CSF) Process, Fluor Engineers and Constructors, Cresap, West Virginia.

Other processes and facilities not discussed in this report are:

1. Bergius Process: (a) German commercial plants (WWII) and (b) demonstration plant, Missouri.

2. Pott-Broche Process: Germany (WWII).

3. SRC Process: Wilsonville, Alabarma.

4. Italian Synthetic Fuel Company (ANIC), Bari and Levorno, Italy, 1936-1940.

5. Imperial Chemical Industries (ICI), Billingham, England, 1935-1939.

6. SASOL, Sasolburg, South Africa.

7. Soviet Union (Siberia) (WWII).

8. Union Carbide Corporation, Institute, West Virginia, 1952-1956.

The COED, CSF, H-Coal, and SRC processes and facilities are described briefly below. ${ }^{1}$

\section{COED (Char Oil Energy Development)}

The objective of the COED project is to convert coal to a low-sulfur synthetic crude oil and medium-Btu gas on a commercial scale. The COED project started in 1962. By 1970, a plant in Princeton, New Jersey, was completed. This plant was capable of handling $36 \mathrm{t}$ of coal per day converting it to low-sulfur, synthetic crude oil. It operated from 1971 to 1974. Currently, the plant is not in operation.

In the COED process, coal is crushed, dried, and then pyrolyzed in a sequence of four fluidized-bed reactors of increasing temperatures [300$\left.900^{\circ} \mathrm{C}\left(600-1600^{\circ} \mathrm{F}\right)\right]$. Hot gases from the fourth stage provide the fluidizing medium for the third and second stages of pyrolysis. The volatiles of the first and second stages are then passed to a recovery system, where gas and oil are produced. Subsquently, the gas is desulfurized and the oil is dehydrated and filtered. This oil is then pressurized [14 MPa (2000 psi)] and reacted with hydrogen in a catalytic reactor to produce the final product.

\section{CSF (Consol Synthetic Fuel)}

The U. S. Energy Research and Development Administration has contracted with Fluor Engineers and Constructors to renovate a pilot-plant facility 
built in the 1960's in Cresap, West Virginia, under the Office of Coal Research. This pilot plant operated from 1966 to 1977 and was beset with many mechanical difficulities. Fluor will not only reactivate and test the facility, but will also operate the plant. A simplified description of the process follows.

Coal (20 t/day) is pulverized and combined with a hydrogenated solvent. The slurry mixture is pressurized to $3 \mathrm{MPa}(400 \mathrm{psi})$ and heated to $380^{\circ} \mathrm{C}\left(730^{\circ} \mathrm{F}\right)$ in a fixed preheater. In the next stage, the slurry passes to an extractor, where liquefaction takes place $\left(400^{\circ} \mathrm{C}\right.$ and $\left.3 \mathrm{MPa}\right)$. The products are then cooled, and the gases are separated. The gas can be used as a fuel after desulfurization. After being gasified, the solids recovered as char provided hydrogen. The coal extract and solvent are then heated to $460^{\circ} \mathrm{C}\left(840^{\circ} \mathrm{F}\right)$ at a pressure of $30 \mathrm{MPa}$ (4200 psi) and subsequently hydrogenated. After pressure letdown and solvent separation, a synthetic crude oil results.

\section{H-Coal}

The H-Coal process is being developed by Hydrocarbon Research, Inc. (HRI), with ERDA, private industry, and the State of Kentucky, In 197.1. HRI started operating (and is still operating) a three-ton-per-day processdevelopment unit and is currently working on a 600-t/day prototype plant to be built in Catlettsburg, Kentucky. In the $\mathrm{H}$-coal process, high-sulfur coal is converted to a clean liquid fuel via a catalytic hydroliquefaction process. Crushed coal is slurried with solvent distilled from the product oil. It is then pressurized to $20 \mathrm{MPa}(2750 \mathrm{psi})$. Hydrogen is added to the slurry and the mixture is heated to $370^{\circ} \mathrm{C}\left(700^{\circ} \mathrm{F}\right)$, then fed to a hydrogenation reactor dissolver. This mixture is charged continuously into an ebullient-bed catalytic reactor. After hydrogenation, the gaseous components are separated. The liquid-solid mixture is sent through a letdown valve, where the solids are separated from the liquid product. Vacuum distillation is used to separate the recycle solvent from the fuel-oil product.

\section{SRC (Solvent-refined Coal)}

The SRC Plant in Ft. Lewis, Washington, started operations late in 1974. This $50-t / d a y$ pilot plant was sponsored by the Office of Coal Research in the late 1960's. The plant was designed by Stearns-Roger Corporation, built by Rust Engineering, and is currently operated by Pittsburg and Midway Mining Company, a subsidiary of Gulf Oil Company.

The SRC process converts high-sulfur, high-ash coal to a low-ash, low-sulfur coal. In the process, the coal is first crushed and then mixed in a slurry mix tank with a solvent derived from the solvent-refined coal. The slurry is mixed with hydrogen and then sent to a preheater at a pressure of $14 \mathrm{MPa}(2000 \mathrm{psi}$ ). Most of the coal is dissolved in the preheaters. The preheater outlet temperature is about $450^{\circ} \mathrm{C}\left(850^{\circ} \mathrm{F}\right)$. The slurry is sent to a hydrogenation reactor-dissolver for further hydrogenation and desulfurization. 
After the dissolver, the product goes to a separator, wheregas is separated from undissolved coal and coal solution. Hydrogen gas is ultimately recovered and recycled. After pressure letdown [from $20 \mathrm{MPa}$ (2800 psi) maximum] of the undissolved coal and coal solution, they are separated from each other. The coal solution is then passed to the solvent-recovery unit, producing the final product: solvent-refined coal. The solvent-refined coal has a melting point of $175^{\circ} \mathrm{C}-200^{\circ} \mathrm{C}\left(350-400^{\circ} \mathrm{F}\right)$, with a $16,000-\mathrm{Btu} / \mathrm{lb}(37-\mathrm{MJ} / \mathrm{kg})$ heat rating.

C. Discussion

Because of high operating temperatures and pressures previously indicated in coal-liquefaction plants $\left[860^{\circ} \mathrm{C}\left(1600^{\circ} \mathrm{F}\right)\right.$ and $\left.30 \mathrm{MPa}(4200 \mathrm{psi})\right]$, and the abrasive solid particles and corrosive environment in processing streams, critical components may fail. To ensure efficient and safe operation of these plants, in-situ monitoring (continuous or periodic) may be required. Many problems found in coal-gasification plants, such as erosion of coal feed lines, stress-corrosion cracking, and corrosion problems such as sulfidation and oxidation may also be found in liquefaction plants. Problems found in gasification plants have not only been associated with corrosive and erosive environments, but also with inadequate mechanical design and improper material specification. For example, problems have been discovered in valve-stem designs and in the generation of large thermal transients during processing.

Argonne National Laboratory is already engaged in the application of nondestructive-evaluation (NDE) methods to monitor erosion in the coalgasification process. Ultrasonic, acoustic-emission, infrared, and radiographic methods have been used in field applications at Synthane (Bruceton, Pennsylvania), Bi-Gas (Homer City, Pennsylvania), HYGAS (Chicago, Illinois), ${ }^{2}$ and $\mathrm{CO}_{2}$ Acceptor (Rapid City, South Dakota). Fürthermore, erosion-monitoring systems using ultrasonic pulse-echo methods for in-situ wall-thinning measurements at elevated temperatures have been installed at Syntinane and Bi-Gas to monitor critical pipe elbows in the coal-gasification process. It is likely. that similar efforts in the coal-liquefaction pilot plants can also be of great benefit in increasing the reliability of the existing and planned systems.

\section{POTENTIAE AREAS FOR APPLICATION OF NONDESTRUCTIVE-EVALUATION TECHNIQUES}

\section{A. In-service Inspection}

1. Wall-erosion Monitoring

One of the most critical areas for application of nondestructive testing is the monitoring of erosion in transfer lines and pressure valves. The most effective method currently available, is the ultrasonic-pulse-echo 
technique. During shutdown, when the pipe or vessel wall is at ambient temperature, no serious problems in principle are encountered. During ultrasonic inspections, there may be problems with accessibility, for example, but modern conventional pulse-echo technique with properly selected probes, electronic equipment, and procedures, can be used to detect changes in wall thickness to an accuracy of 0.05-0.25 mm without difficulty, depending on geometry, wall thickness, frequency of probe employed, and skill of the operator.

For in-service monitoring at elevated temperatures $\left(500^{\circ} \mathrm{C}\right)$, however, the problems become formidable. Difficulties are encountered with couplants used for manual scans as well as with wedges and crystals, which, although effective at room temperatures, may not be satisfactory at temperatures up to $500^{\circ} \mathrm{C}$. The problems encountered in ultrasonic scans at elevated temperatures are associated with the loss of signal across the couplant, evaporation of the couplant, variation in attenuation of the wedge (or waveguide) material, changes in wall thickness because of material expansion, and total failure of ultrasonic probe or loss of ultrasonic crystal efficiency at high temperature.

To eliminate these problems, a cooled waveguide welded to the pipe outer diameter could be used for continuous monitoring at high temperature. The transducer temperature is reduced to a manageable level, and the waveguide is welded to the pipe to eliminate coupling problems. In this case, of course, wall-thickness measurements are made at fixed points only and the system could be very cumbersome if many points are to be monitored.

Recently, such pipe-wall monitoring systems employing finned waveguides (for cooling) have been installed by the Argonne National Laboratory INDT Group at the Synthane and Bi-Gas Coal Gasification pilot plants. These systems use commerically available transducers and pulser-receiver systems to monitor a transfer tee, a 60 and a $90^{\circ}$ bend.

Most of these systems appear to be working satisfactorily. Nevertheless, more advanced designs may use variations of this initial work. For example, the relative effectiveness of longitudinal and transverse waves should be established because of the difference in mode conversion at waveguide-toair boundaries and sensitivity variations from differences in velocity of sound between shear and longitudinal waves at a given frequency. The advantages of employing radio frequency waves, with a pulse overlap method of measuring transit times between echos, needs to be evaluated, and the possibilities of using different waveguide materials (ceramics or metal alloys), bonding methods, and crystals (e.g., quartz or lithium niobate) need to be explored.

The possibility of a simple modified waveguide (or buffer-rod) system for continuous manual or automated scans at high temperature should be explored. With ceramic materials for waveguides, commercially, available or yet to be developed high-temperature couplants (e.g., Hi Temco or Pyrogel), and high-temperature crystals (e.g., lithium niobate), continuous 
wall-thickness monitoring at elevated temperatures may be possible. Development work along these lines is clearly needed. Environmental effects on permanently installed ultrasonic-monitoring systems and long-term stability also have to be evaluated. The NDT group at ANL is planning to evaluate the longterm weathering effects on installed ultrasonic wall-thickness monitoring systems for the coal-gasification program. Additional work in this area will be needed, however.

Although electromagnetic acoustic transducers (EMAT's) are not commercially available in this country, they could have application for wallthickness measurements at elevated temperatures. In this type of device, acoustic waves are generated in a metal by placing a source of electromagnetic field ( $r f$ coil) near the surface of the specimen while the $r f$ source is in the presence of a strong static magnetic field. The induced eddy currents interact with the material to produce ultrasonic waves (shear, longitudinal, or surface waves). The ultrasonic waves are detected by the inverse process. ${ }^{3}$

The advantage of this type of ultrasonic device is that it is completely noncontacting. For elevated-temperature wall-thickness measurements, this system could be used without a couplant. The disadvantage is that the sensitivity is down significantly from conventional ultrasonic probes $<50 \mathrm{~dB}$ for mild steel, $45 \mathrm{~dB}$ for aluminum). ${ }^{4}$ Despite this difficulty, EMAT's have been shown to be effective in many situations ${ }^{5}$ including flaw detection in a steel bar at elevated temperatures. ${ }^{6}$

Research and development work with electromagnetic acoustic transducers should be carried out with the specific goal of applying the technology to wall-thinning monitoring in coal-liquefaction plants.

Another area of ultrasonic testing that has application to erosion monitoring is ultrasonic spectroscopy. Ultrasonic-spectroscopy techniques have the potential to assess the extent of erosion/corrosion in terms of surface roughness as well as wall thinning. ${ }^{7}$ Current work in ultrasonic spectroscopy for rough surfaces is discussed in Ref. 8. Experimental results are shown that indicate that spatial periodicities can be deduced from the spectral content, of the ultrasonic signal.

Applications of spectrum-analysis techniques may prove valuable in erosion monitoring. Development work for application to coal-liquefaction plants should be carried out.

\section{Plugging of Lines}

Plugging of transfer lines is a constant problem (SRC), and a method to locate the "plug" would save considerable time over the methods used now to correct the problem. Some problems also were evident at the $\mathrm{H}$-coal plant in a separator overhead steam line (ammonium chloride deposits). 
Several techniques have potential for locating the point of plugging in transfer lines. X radiography, which could be used without disturbing the system, could be successful, as line plugging might detectably affect the absorption of $X$ rays crossing the pipe. The problem is the expense, inconvenience, and difficulty associated with poor accessibility in many plant areas. A portable gamma source is required, which makes evacuation of the area essential during film exposure. The necessity for extensive mapping of the pipe makes radiography costly and time-consuming. Development of more efficient and inexpensive examination of piping employing possibly remotely controlled, traveling $X-r$ y counters may be in order.

Plugging of a line may result in a temperature gradient across the, plugged area if the piping does not dissipate the heat. tonn effertively, and if pipe insulation is absent or can be removed easily. Infrared techniques may be able to locate the point of plugging in a line. Portable infrared cameras such as the AGA 750 could be used to detect a plug location rapidly and effectively. Temperature variations as small as $0.2^{\circ} \mathrm{C}$ can be observed with stateof-the-art equipment.

Acoustic techniques may be useful in locating plugs. At audible frequencies, the presence of a plug may affect the resonance or propagation of waves through or across the pipe, indicating an anomalous situation. Exploratory work would be necessary to determine the effectiveness of acoustic methods.

\section{Hot.-spnt Mnnitnring}

The presence of eroded walls in pressure vessels and piping and anomalous behavior of critical systems (such a.s the rarbnnizer at C.resap) can result in excessive temperatures. These high-temperature areas or "hot spots" may be detectable by infrared techniques. The application of infrared cameras (such as AGA 750) for thermal inspections is not new. For example, AVMCO has reported successful thermal monitoring of a steel plant including the detection of hot spots. There are difficulties, of course. These are associated with limited resolution and variations in infrared emissions associated with geometry and emissivity variations. As a result, data interpretation becomes difficult. Nevertheless, it seems that infrared monitoring of coal liquefaction plants is feasible and can save on downtime and produce information concerning the operation of various processes.

\section{Letdown Valves}

Letdown valves [from pressures up to $30 \mathrm{MPa}(4000 \mathrm{psi})$ ], such as those at SRC and Cresap, have a very short life (2-4 weeks) because of the severe erosion. Monitoring of these valves may be useful to indicate the state of wear. One potential method for detecting wear states is acoustic monitoring. In principle, the noise generated at the valve could be related to the leak rate. 
Sawley and White 9 have discussed at length the problem of gas-valve noise. One major difficulty in monitoring valves acoustically and relating quantitative data to leak rate or state of wear is that the system processing variables are not constant and a variety of acoustic signals, changing in time, will be associated with one state of wear.

Nevertheless, despite these potential difficulties, a program at $A N L^{10}$ on valve leakage has shown some promising results. This work is being carried out in an effort to acoustically monitor valve leakage in coal-gasification pilot plants. An effort to correlate acoustic signals (including amplitude and spectral content) with valve leakage in coal-liquefaction plants would also be worthwhile.

\section{Detection of Flammable Leaks}

Leaking seals and flanges have led to small fires in at least one pilot plant (H-Coal). There is a clear need for an effective leak-detection system in areas where leaks of flammable substances can result in potentially serious fires. OSHA may make standards even stricter than they are now. Effective placement of acoustic sensors may enable small leaks to be detected before serious problems are encountered.

Another means of detecting leaks is with an ultraviolet detector. The presence of flammable substances in the air around leaking seals and flanges can modify the absorption characteristics of an ultraviolet beam. An ultraviolet detection device is currently being used at $\mathrm{H}$-coal.

Other devices are available for detection of a variety of gases: for example, a diode tester for halogens, a mass spectrometer for helium, and an infrared detector for nitrous oxide. There is also a device for detecting freon, carbon dioxide, etc. An evaluation of the state of the art for gas detection and identification of flammable gases in cual-liquefaction processes could be useful to find the mnst rnst-effertive system for early detection of flammable leaks.

\section{Bearing and Pump Wear}

The failure of pumps and bearings (e.g., SRC and CRESAP) because of excessive wear is annther area of concern. Monitoring may be necessary to predict critical-component lifetime and anticipate failure to avoid catastrophic situations. Acoustic sensors and accelerometers could be used to indicate the state of wear of critical machinery. Acoustic and vibration signature-analys is studies are discussed extensively in the literature. ${ }^{11-13}$ Advances in sophisticated electronic devices, correlation techniques, and minicomputers have made signature analysis a powerful diagnostic tool for machine performance. 
In high-speed rotary equipment, vibration levels can be correlated to bearing instabilities, blade vibrations, and seal failure. ${ }^{11}$ There appears to be a need in coal-liquefaction plants for signature analysis to improve the life predictions of critical components and prevent catastrophic failures in pumps, valves, bearings and other mechanical devices.

\section{Nondestructive Evaluation for Microstructural Changes}

There is a need to understand the stress-or temperature-induced microstructural changes in pressure vessels (CRESAP) ${ }^{14}$ and possibly other critical components (transfer lines and other internal parts). Several NDE methods may provide useful information concerning material microstructure. These are nuclear magnetic resonance, X-ray diffraction, Mös sbauer analysiś, and acoustical microscopy. The most likely candidate for investigating bulk microstructural changes associated with grain-size variations is ultrasonic spectroscopy. ${ }^{15}$ Variations in frequency spectra of transmitted or reflected ultrasonic signals can be significant as grain size varies. In addition, this type of analysis is adaptable to in-service inspection.

Mössbauer analysis, in which resonance absorption or emission of gamma radiation is used to determine composition, can be useful for insitu and diagnostic applications for coatings, substrate deterioration, and corrosion products. There are severe limitations, however, because of the difficulty in applying this technique in the field, particularly in the environment of liquefaction plants where accessibility may severely limit the technique. The method requires close proximity to the specimen surface and precise vibration of a radioactive source. In addition, there is a radiation hazard.

The nuclear-magnetic-resonance technique, in which radiofrequency waves are applied to the material to induce nuclear spin resonances that are characteristic of the material lattice structure, may have some limited application for coal-liquefaction-plant components. This technique, however, only works with material containing nuclei with magnetic moments and only applies to surface areas. Close proximity to the sample is required. Nevertheless, the data obtained are sensitive to impurities and material composition and detect material variations on the order of $10 \%$.

$X$ - ray diffraction techniques may also provide information concerning the microstructure of a particular component by evaluating the Bragg peaks obtained in scattered radiation. This technique is also limited to surface phenomenon, and although portable equipment is availablc, application to field work may be difficult.

Of the four methods mentioned, only the acoustic-spectroscopy technique would generate data on bulk microstructural changes. Development work would be needed before these methods could be applied directly to coalliquefaction applications. Nevertheless, the need is present, and efforts to detect microstructure variations in situ should be carried out. 
8. Fluidized-bed Level Detection

Liquefaction processes have fluidized or slurry (SRC) beds or catalyst levels (H-Coal) to monitor. Knowledge of the level of the bed can be critical for efficient operation of the plant. In current techniques for determining the bed level, differential-pressure taps and nuclear-density gauges are used. The pressure taps are not entirely satisfactory, as they become plugged and can require extensive maintenance. The nuclear-density gauge may not work for scaled-up systems because of the excessive absorption in the vessel walls.

Various techniques will have to be explored to establish a method to measure fluidized-bed or catalyst levels. These include acoustical, possibly taking advantage of variable attenuation of low-frequency waves above and below fluidized beds; nuclear, where sensitive detectors may detect variations in absorption of gamma rays or neutrons above and below the bed; and electromagnetic, where energy pulses are transmitted down to the fluidized-bed interface and reflected pulses are detected to establish the interface location.

In this last technique ${ }^{16}$ (time-domain reflectometry), a conducting wire extending down the vessel wall carries the electrical pulse. Work at the Pittsburgh Energy Research Center has demonstrated that this technique is. feasible for small systems. ${ }^{16}$ Carrying this technique to larger plants and establishing sensitivity and reliability will require an extensive effort, however.

\section{Heat Exchangers and Heater Coils}

The erosion/corrosion problems, general fouling of heat exchangers (CRESAP), and failure of the heater coil of a preheater (SRC) suggest a need for in-service inspection devices for critical components. For in-service inspection, only boreside inspections of the tubing will be feasible. Probes would have to be developed that can travel through tubing. while inspecting it. Two possibilities exist for such a device: an ultrasonic probe or an eddycurrent probe. The feasibility of using an ultrasonic probe has been demonstrated $^{17}$ for a nuclear-reactor steam generator. A multiple-crystal ultrasonic probe travels in the tube while ultrasound is coupled to the tube wall by water in the tube.

A unique pulsed eddy-current device has also been developed by the ANL NDT Group and has been used successfully by industry. It could be readily adapted for use in steam-generator or preheater lubing.

Other less sensitive eddy-current devices are routinely used for in-service inspection of steam-generator tubing. The ultrasonic probe has the advantage of better characterizing an anomaly, whereas the eddy-current. probe may be more sensitive to smaller defects and does not require a coupling medium. Before these devices can be used, probes would have to be adapted 
for the needs of liquefaction plants. Difficulties associated with geometry (e.g., sharp bends or tube eccentricity) may severely limit these devices as inspection tools. A reasonable effort would be needed to establish the ultimate effectiveness of ultrasonic or eddy-current probes for in-service inspection of liquefaction-plant steam-generator or preheater tubing.

\section{Detection of Stress-corrosion Cracks}

Stress-corrosion cracks can and have been identified in coalconversion systems [e.g., weld neck flange from Synthane Pilot Plant steam line and rabble arm (stirrer) for Morgantown Energy Research Center gas producer]. There is a need to identify potentially susceptible areas and develop effective means for inspecting liquefaction plants while in servire. Considerable effort has already been exerted to evaluate ultrasonic techniques for detecting stress-corrosion cracks in stainless steel nuclear-reactor piping. ${ }^{18,19}$ Considerably more effort is needed to develop highly reliable conventional (ultrasonics) methods as well as explore the newer techniques (e.g., acoustic holography and acoustic emission) for application in liquefaction plants. Problems that arise for wall-thickness monitoring such as finding effective couplants, crystals, and wedges (or buffer rods) for elevated temperatures also would apply for ultrasonic inspections for SCC.

In addition, the problems occurring in ultrasonic inspection of welds in nuclear-reactor piping such as the weak signals from SCC, interpretation of signals (distinguishing from geometrical reflectors), and poor assessibility would also be present in liquefaction plants. Although small cracks ( $<0.5 \mathrm{~mm}$ deep) may be difficult to detect in areas close to welds $(<1.0 \mathrm{~cm})^{18}$ manual ultrasonic scans could still be very valuable for detecting non-through-wall stress-corrosion cracks in liquefaction plants.

A Battelle (Pacific Northwest Laboratories) study to investigate a continuous surveillance method involving acoustic-emission technology ${ }^{19}$ has shown promising results. In this effort, an advanced monitoring system has been developed. A permanent record of acoustic-emission (A.F.) data is maintained by a digital memory. AE signals are also identified by location so that isolated areas can be interrogated.

Because of the potential for untimely or even catastrophic failure due to the initiation and propagation of stress-corrosion cracks, development work should be carried out to improve current methods to detect stresscorrosion cracks and develop and apply newer techniques such as acoustic emission and acoustic holography to coal-liquefaction plant.s.

\section{Relation of Quantitative NDE to Fracture-mechanics Models}

The ultimate objective of nondestructive evaluation is to establish the probability of failure of a structural component. With present state-ofthe-art equipment, flaws can be detected that are smaller than those that can 
cause imminent failure. If the size, shape, and orientation of a flaw can be established, the probability of failure may possibly be estimated. With quantitative data from a flaw such as can be obtained using ultrasonic methods, it may be possible to distinguish between critical and benign flaws. Also, smaller safety margins may be reached with more detailed analysis of defects.

For situations in which failure occurs by crack progagation, fracture-mechanics models are well established. When NDE techniques such as ultrasonics can be used to size the crack, the probable time to failure can be estimated at a particular confidence level from knowledge of the critical flaw size, which may vary from 1 to $25 \mathrm{~mm}$ in metals. An increase in the ability to characterize the material (e.g., crack-propagation resistance and its defects) will increase the confidence in predicting lifetime.

Various techniques are being examined to improve the quantitative ultrasonic data obtained during a component inspection. ${ }^{20}$ These include (1) ultrasonic spectroscopy (frequency content of the scattered ultrasound is interpreted to identify the geometry of the defect), (2) electronically scanned and focused ultrasonic arrays for producing real-time images, (3) a randomsignal correlation system for ultrasonic flaw detection for improved signalto-noise ratios, (4) acoustic microscopy for improved resolution and observation of microstructure and fracture propagation phenomenon, and (5) acoustic holography for improved size and shape characterization of anomalies. Most of these techniques are discussed at length in Ref. 21 .

A need exists to improve the reliability of quantitative data so that failure due to crack propagation can be predicted from fracture-mechanics models. More extensive research and development will be needed to reach this objective.

12. Establishment of On-line Test Facilities for Measuring Erosion Effects

At the CRESAP Pilot Plant, a bypass line will be installed to obtain erosion data. This type of facility could not only provide data on erosion effects, but could also provide a staging area to test various erosion-monitoring devices such as the ultrasonic devices discussed earlier. More facilities of this type are needed. The opportunity would then exist to establish the feasibility, accuracy, and reliability of conventional and unconventional (e.g., waveguides, acoustic-electromagnetic devices, or ultrasonic spectroscopy) NDE techniques.

\section{B. Preservice Inspection}

1. Improved Inspection of Heavy Sections

In the Workshop on Materials Problems and Research Opportunities in Coal Conversion, ${ }^{14}$ the need for improving NDE of heavy sections 
(i.e., pressure vessels) was mentioned. Conventional ultrasonic and radiographic methods are currently used for inspecting pressure vessels. Improvements over current methods may be achievable by techniques such as acoustical holography, acoustic-emission testing, adaptive nonlinear signal processing, $\mathrm{X}$-ray tomography, radiographic-image enhancement, and automated and computerized ultrasonic scanners.

These techniques enable better characterization of material anomalies and better imaging of flaws. Some of them are discussed briefly below.

An ultrasonic imaging system for nuclear-reactor pressure vessels is described in Ref. 22. A near-real-time ultrasonic pulse-echo and acousticalholography system is in the development stages. The objective of the system is to size, shape, orient, and locate material anomalies in a pressure vessel. This is to be carried out with a multielement ultrasonic array, coupled to a computer and to mechanical and display systems for conventional and holographic modes of operation. This system could provide the most advanced data acquisition and analysis available for pressure vessels. Acoustical holography for defect detection in pressure-vessel materials is also described by Holt in Ref. 23.

The application of acoustic-emission monitoring to pressure vessels has been shown to be feasible. Reference 24 describes the results of one group of investigators. Here, tests of welded-steel and-aluminum vessels showed that structural failure due to fatigue crack growth, as well as subcritical crack growth resulting from stress-corrosion cracking or hydrogen embrittlement, can be detected by acoustic-emission proof-testing. In these tests, the vessel is periodically overpressurized while simultaneously monitoring for acoustic emission. If some type of crack extension has occurred since the previous test, then new acoustic emission will be generated during the current test. If no changes have occurred then, and if the previous test pressure is not exceeded, no new emissions will be detected. Thus, by periodic testing, the presence of subcritical crack growth may be detected. This system is useful for both preservice and in-service inspections. More recent work is described in Ref. 25.

A new nonlinear NDE signal-processing technique has been developed for aerospace application by Adaptronics, Inc., and Babcock and Wilcox. ${ }^{26}$ Rather than using only amplitude information in ultrasonic inspections, many ultrasonic parameters are synthesized to arrive at a description of the anomaly. Inputs such as power spectrum and "cepstrum" are used. This technique has shown to be promising in characterizing and detecting flaws not possible by other conventional ultrasonic means.

Automated systems can also enhance the reliability in ultrasonic inspections. Such a system for light-water reactors is described in Ref. 26. 
The system is for in-service as well as preservice applications. The system has remotely controlled carriers for the ultrasonic probes and a computer system for providing real-time readout data.

By the ultimate application of one or more of these NDE methods, significant improvements can be made in the reliability of liquefaction-plant pressure vessels and related equipment.

\section{Improved Inspection of Welds}

On page 495 of Ref. 14 it is mentioned that "Required welds of adequate quality could not be made with today's NDE standards to me asure quality." By the proper application of one or more techniques already described in this chapter, the quality control of welds can be improved. Autornated ultrasonic acanning of completed welds with computerized data handling may be one method, for example. ${ }^{27}$ Improved NDE standards (more closely resembling the actual weld in terms of material and geometry) and/or welds designed with careful thought to the application of nondestructive testing (i.e., smoothed weld roots and crowns) may also lead to better welds.

In addition, acoustic-emission monitoring has been shown to be useful during welding. For example, excellent correlation has been demonstrated between detection of artificially induced and naturally occurring flaws by $X$-ray methods and acoustic emission during welding of tank cars at the General American Transportation Corp. ${ }^{28}$ Real-time acoustic monitoring does appear feasible. ${ }^{29}$ Application of these techniques to welds in coal-liquefaction plants could lead to significant improvement in quality control.

\section{Summary}

Nondestructive-examination (NDE) needs for coal liquefaction have been assessed by acquiring information from kno:vledgeable personnel in government and industry, making site visits to existing plants, and reviewing relevant publications. As a result, NDE is highly rated ${ }^{14}$ in importance as a way to help solve problems in coal-conversion systems. These problems are as sociated primarily with the highly erosive and corrosive slurries being transferred and pumped throughout the coal-conversion process. The effects of erosion are exaggerated by the high level of abrasives, the high velocity of the slurries, and elevated temperature and pressure $\left[800^{\circ} \mathrm{C}\left(1600^{\circ} \mathrm{F}\right)\right.$ and $30 \mathrm{MPa}(4200 \mathrm{psi})]$. In particular, a great need exists for automatic monitoring of wall. thicknesses where erosive wear is significant, such as at sharp turns and points of excessive turbulence. General NDE problem areas in liquefaction plants exist in transfer lines, valves, pumps (pump casings), heat-exchanger tubes, pressure vessels, welds, and bearings. Some ultrasonic testing during shutdown is being carried out at SRC Ft. Lewis to assess erosion.

"Overall, the areas of NDE application appear rather large, encompassing better in-service inspection procedures and improvement in techniques used 
for plant construction. Application and development work seem appropriate in several areas including high-temperature ultrasonics (in-service erosion monitoring), acoustic emission (welding, valve, and pump monitoring), radiography (preservice and possible in-service inspection), acoustic holography (large-section inspections), and ultrasonic spectroscopy (material microstructural changes).

Table I identifies the primary areas for the application of NDE techniques and indicates specific applicable methods, as well as the areas requiring development effort.

TABLE 1. Potential Arcas of Application for NDE

Techniques in Coal Liquefaction

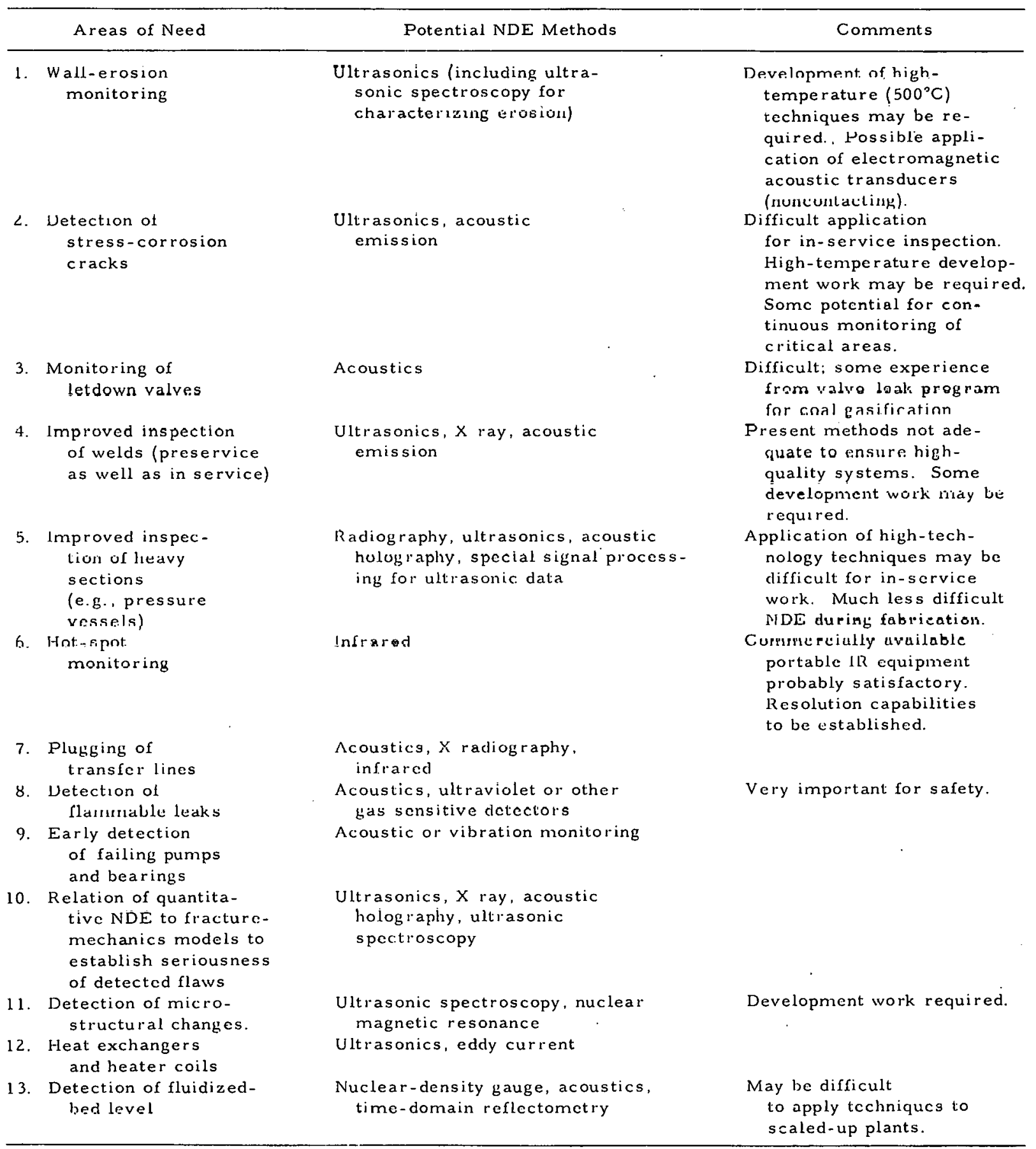




\section{APPENDIX A}

\section{Literature Search}

1. Literature-search Procedures

A search has been made for relevant papers on coal liquefaction available in the open literature. A computer search of the literature encompassed the period 1969-1976. The information-retrieval systems used were (1) Lockheed Corp. (California) Dialog System employing NTIS, Chemical Abstracts and Engineering Index data bases, and (2) ERDA RECON System employing the ERDA energy data base. Additional significant citations were obtained by manual searches of (1) the ERDA Energy Research Abstract titles from March to October 1976, (2) Coal Processing, Production, and Properties Bibliography (TID-3349-SlPl) (6757 Citations 1974-1976), and (3) Coal Processing Bibliography (TID-3349) (7441 citations, 1930-1974). Additional reports and preprints were obtained as a result of personal contacts and site visits.

2. Summary of Literature Review

Nondestructive evaluation (NDE) is highly rated in importance as a way to help solve problems in coal-conversion systems. ${ }^{14}$ These problems are associated primarily with the highly erosive and corrosive slurries being transferred and pumped throughout the coal-conversion process. The effects of erosion are exaggerated by the high level of abrasives, the high velocity of the slurries, and the elevated temperature and pressures $\left[860^{\circ} \mathrm{C}\left(1900^{\circ} \mathrm{F}\right)\right.$ and $3 \mathrm{MPa}(4200 \mathrm{psi})]$. A need exists for automatic monitoring of wall thicknesses where erosive wear is significant, such as at sharp turns and points of excessive turbulence. General problem areas in liquefaction plants are transfer lines, valves, pumps (pump casings), heat-exchanger tubes, pressure vessels, welds, and bearings.

Conventional NDT techniques are currently being used in preservice inspection of pressure vessels and welds following ASME Boiler and Pressure Vessel Codes and ASTM specifications. Some in-service inspection is also being carried out (SRC). Nevertheless, there is a significant need for improvement in NDE to improve quality control and to obtain more quantitative data which can be related to fracture-mechanics analysis. An understanding of stress and temperature induced microstructural changes has also been mentioned as a critical need. ${ }^{14}$ Other specific needs (and methods) for nondestructive evaluation are:

a. Improvement of NDT of welds to achieve a high-quality product (acoustic emission monitoring, radiography, and ultrasonics).

b. Monitoring of erosion of critical transfer lines at elevated temperature [ultrasonics at temperatures to $900^{\circ} \mathrm{F}\left(480^{\circ} \mathrm{C}\right)$ ]. 
c. Monitoring of bearing wear (acoustic or vibration monitoring).

d. Monitoring of wear of pumps and letdown valves (acoustic).

e. Detection of plugging of transfer lines (radiographic, ultrasonic, and infrared).

f. Leak detection at seals, flanges and end closures to contain dangerous fluids (acoustics and infrared).

g. Hot-spot monitoring of lines and vessels (infrared), e.g., reactor vessel at Cresap.

h. Leak-monitoring systems, e.g., filter section of mineral-separation unit.

i. Wear monitoring of process-resistant coatings.

j. Preservice inspection of pressure vessels (radiography, ultrasonics, acoustic holography, and dye penetrants).

k. In-service inspection of heat-exchanger tubing (eddy current and ultrasonics).

The areas of NDE application include improved in-service inspection procedures and techniques for plant construction. Application and development work is needed in (1) high-temperature ultrasonics (in-service erosion monitoring), (2) acoustic emission (welding, valve, and pump monitoring), (3) radiography (preservice and possibly in-service inspection), (4) acoustic holography (large-section inspections), and (5) ultrasonic spectroscopy (material microstructural changes).

\section{Review of Selected Papers}

Many publications were reviewed in an effort to identify areas in coalliquefaction plants where nondestructive evaluation is needed. The relevant information from the publications reviewed is discussed belnw.

a. Materials Technology in the Near Term Energy Program, National Academy of Science, Washington, D.C., 1974 (Ref. 30)

This is a brief study of the near-term energy program (1985) for the United States. Areas are identified in which materials technology may play a significant role. This report of the Ad Hoc Committee on Critical Materials Technology in the Energy Program discusses the considerable erosion present in coal-liquefaction plants and major degradation of materials formerly assumed to be erosion-resistant.

In addition to erosion problems, corrosion is also troublesome. This report points out that stellite- and cobalt-bonded tungsten carbide is not resistant to corrosion in sulfidation environments. As a result of these 
severe conditions, the text.specifically mentions that "a particular need is for automatic monitoring systems for continuous measurements of wall thickness where erosive wear is significant."

It is also pointed out that equipment for handling sour water (containing hydrogen sulfide, ammonia, chlorides, etc.) produced by the liquefaction process will experience severe corrosion. Piping, pumps, and condensers are the principal problem area. Austenitic stainless steel equipment has failed in as little as $1-2$ weeks.

The suggestion that wall thicknesses be monitored continuously could entail the application and possibly further development of elevatedtemperature ultrasonic techniques.

b. Coal Liquefaction Design Practices Manual, Electric Power Research Institute (EPRI) Report AF-199 (Project 409-1), July 1976, Prepared for EPRI by Fluor Engineers and Constructors, Inc., Los Angeles ${ }^{1}$

This report assembles data on past and present experiences of coal-liquefaction pilot plants in order to define the problems associated with these systems. The manual identifies and analyzes equipment and material failures under actual operational conditions. Several conclusions from this report are:

(1) The major design and materials problems a re due to the presence of solid/gas or solid/liquid mixtures.

(2) Lack of knowledge in several areas (high-pressure coal slurry charge pumps, preheaters, and high-pressure letdown equipment) is preventing proper design of equipment.

(3) More emphasis is needed in the development of mechanical hardware.

A recommendation is made to establish equipment development programs where insufficient data are presently available for the development of rommerrial plant.s.

Erosion/corrosion tendencies are more pronounced at sharp turns in piping and points of excessive turbulence. These effects are aggravated by increases in the quantity and size of abrasives and the high velocities of particles. For high-velocity particles, an impingement angle on the order of $30^{\circ}$ yields the greatest erosion. In coal-liquefaction processes, streams reach temperatures of $500^{\circ} \mathrm{C}$, pressures of $3 \mathrm{MPa}(4000 \mathrm{psi})$, and slurries with up to 50 wt $\%$ of coal particles. These slurries are pumped, stirred, and throttled and lead to severe service conditions. 
As an example, in the SRC Plant in Tacoma (Ft. Lewis), reduced tube-wall thicknesses of about $2 \mathrm{~mm}$ in an Incoloy 800 preheater coil was observed and attributed to erosion. After the initial run, however, no further erosion was noted. Corrosion problems have also been noted in the SRC solvent-recovery system. Major erosion problems have been reported at Cresap, where pressure letdown valves have a life of less than 60 days continuous service. $\mathrm{Ni}$-hard nozzles at Cresap handling $25 \%$ coal slurry at $1800 \mathrm{kG} / \mathrm{h}(4000 \mathrm{lb} / \mathrm{h})$ experienced erosion rates of about $1 \mathrm{~mm}$ per $100 \mathrm{~h}$ of operation.

An example of pump problems is the failure of slurry circulationpump casings (stainless steel) at Cresap due to the abrasive service. In one instance, the case wore through completely. The slurry pumped is 50 wt $\%$ coal in a solvent base, and the pump is required to deliver $20 \mathrm{gpm}(1.26 \mathrm{x}$ $\left.10^{-3} \mathrm{~m}^{3} / \mathrm{s}\right)$. Other pump problems involve erosion of impellers, stators and valves.

Problems have also been observed in heat exchangers due to high pressures [3 $\mathrm{MPa}(4200 \mathrm{psi})]$ and high temperatures [ $\left.480^{\circ} \mathrm{C}\left(900^{\circ} \mathrm{F}\right)\right]$. At. Cresap, tubes were severely deformed during service. At an SRC Plant (Alabama), a seal weld at the tube-to-tubesheet junction developed a crack, leaking effluent that caused a fire. At the SRC Plant (Tacoma), the heat exchanger was abandoned because of excessive problems with leaks. Seal failures have also been noted in pumps and centrifuges.

'L'he problems discussed above indicate a need for in-service NDE to measure erosion and initiation of cracks in tubing and vessels and to determine the remaining useful life of pumps and valves.

Although there are many areas where NDE can yct be applied, conventional techniques are currently being applied to plants during construction phases. This includes radiography and ultrasonic testing. Welds are radiographed. Ultrasonic testing may be used for high=pressure vessels. Magnetic particles and liquid penetrant may also be used for testing steel plates. All inspections follow the codes specified by the ASME Boiler and Pressure Vessel Codes (Section VII) and ASTM specifications (ASTM-A-578$716,-E-138,-E-165,-A-388-71,-E-428$, etc.). This design-practices manual also has a useful list of references containing 120 entries.

c. Workshop on Materials Problems and Research Opportunities in Coal Conversion, Sponsored by the National Science Foundation and the Office of Coal Research, Organized by the Department of Metallurgical Engineering, Ohio State University, R. W. Staehle, Workshop Director, April 16-18, 1974, Columbus, Ohio ${ }^{14}$

This workshop was organized to identify and evaluate materials problems in coal-conversion systems that may limit their performance. 
Recommendations were made for research and development work which would improve the reliability and efficiency of synthetic-fuel plants. The recommendations were evaluated by the workshop attendees and given a priority rating.

The proceedings of this conference indicate several areas of need for NDE. As in previously discussed papers, the problems associated with erosion and corrosion of transfer lines, pumps, and valves were discussed. As one area for potential development for coal-conversion systems, NDE was rated highly by the workshop as to its importance in helping solve the problems associated with coal-conversion systems. Several specific areas or needs for NDE were mentioned.

(1) Develop surveillance methods for the plant, with particular emphasis on in-service inspection techniques for on-site evaluations.

(2) Develop NDE for heavy sections (i.e., welded components), and relate quantitative data to fracture mechanics. Acoustic holography was one method mentioned.

(3) Develop sensors for detecting erosion in pipes.

(4) Provide a basis for quality control and testing. (This would encompass many NDE methods.)

(5) Develop techniques for predicting material lifetime.

(6) Understand the stress or temperature-induced microstructural changes in pressure vessels operating under creep conditions. NDE. has the capability to make measurements suggesting microstructural variations (i.e., ultrasonic-frequency analysis).

(7) The safety and reliability of the plant depends on proper welding. Required welds of adequate quality are not necessarily possible under current NDT standards. Improve NDT methods, particularly monitoring during welding. (Acoustic-emission monitoring may provide useful quantitative data.)

d. Reliability Problems in Coal Gasification and Liquefaction, by H. E. Frankel, Mechanical Failures Prevention Group Symposium on Prevention of Failures in Coal Conversion Systems, April 2l-23, 1976, Battelle-Columbus Laboratory, Columbus, Ohio

This paper discusses the significant reliability problems in coalconversion systems. It presents the failure-avoidance work being carried out under ERDA sponsorship at government and industrial laboratories. It points out that the lack of a domestic industry and thus the lack of commercial plants imply that reliability data a re not conveniently available or are nonexistent. ERDA pilot and demonstration plants would be the best source of data. 
Results of some failure analyses conducted at ERDA pilot plants is presented. The most frequent known causes of failure are sulfidation and erosion (physical abrasion). Frequently, however, the cause is undetermined. The failure-analysis data seem to suggest that many failures are a result of poor quality control, fabrication, or design. Two ERDA-sponsored NDE programs are mentioned: (a) the Argonne National Laboratory Program for nondestructive testing for coal-conversion-plant components (coal gasification), where estimates of materials and component-life expectancy are the goal, and (b) the Oak Ridge National Laboratory Program for inspecting wear and process-resistant coatings by in-situ NDE methods (mainly in coalgasification plants). These efforts might develop methods that are applicable as well to the coal-liquefaction pilot and demonstration plants.

e. Overview of Material Problems in Coal Liquefaction Pilot Plant, W. Hong and J. Richards (Fluor Corporation). Presented a.t NACE National Meeting, Houston, Texas, March 26, 1976 (Ref. 32)

This paper discusses materials problems in various U. S. pilot plants, but concentrates on operating experiences at the Cresap, West Virginia, plant. The three critical areas discussed are pressure vessels, pumps, and letdown valves. The following problems were discussed:

(1) Severe wear of bearings of the agitator shaft of the extractor vessel resulting in excessive vibration (Cresap).

(2.) Fixcessive vibration and overheating (due to refractory lcver cracking) of the low-temperature carbon reactor vessel (carbonizer). This vessel is designed for $0.1 \mathrm{MPa}(15 \mathrm{psi})$ and $480^{\circ} \mathrm{C}\left(900^{\circ} \mathrm{F}\right)$.

(3) Trailure of packing in coal-slurry pumps due to the abrasive nature of coal particles.

(4) Difficulties with erosion of pressure-letdown valves at Cresap, H-coal, and SRC plants.

Some NDE methods not discussed previously are suggested by these problems. One is acoustic monitoring. The application of acousticemission technology or vibration monitoring may be useful for early detection of wear in critical components such as the extractor vessel, letdown valves, and pumps mentioned above. Infrared monitoring might give a valuable early warning of failure in components such as the carbonizer (Cresap) as discussed in (2) above. 
f. Materials Considerations in Coal Liquefaction, J. B. O'Hara, W.J. Lochmann, and N. E. Jentz, Metals Progress, November $\underline{1976(\text { Ref. 33) }}$

This paper reviews the coal-liquefaction process, compares the various plant operating conditions, and discusses many problems associated with these systems. As discussed in previous papers, the erosion/corrosion problems are pointed out as being severe. Lack of adequate slurry pumps and letdown valves is mentioned as well as the difficulty in predicting material loss with reliability. Problems associated with slurry preheaters are anticipated for a commercial-level SRC plant, although performance has been satisfactory in general at the pilot plant. Other problems mentioned at SRC are the failure of steel U-tubes and Type 410 stainless steel fractionating trays of the product recovery section (fractionating columns and reboiler). Potential problems are anticipated in the dissolver (SRC), in which the coal slurry is hydrogenated and which is exposed to a corrosive environment, and in large pressure vessels subject to corrosion from hydrogen sulfide $\left(\mathrm{H}_{2} \mathrm{~S}\right)$ and stress-corrosion cracking (pipes and/or vessels) due to the presence of chloride.

Various NDE methods are needed to help minimize the effects of the problems. These methods have been discussed in previous paper reviews.

g. Pipe System Erosion and Hydraulics Analysis at the Cresap Pilot Plant, Fluor Engineers and Constructors, Incorporated, Los Angeles, May 1976, FE-1517-32, prepared for ERDA ${ }^{34}$

This report presents the results of a study to establish a program to improve the design of the piping configurations in coal-liquefaction plants. Special rigs are recommended to test piping components for erosion in several key coal-slurry streams at Cresap. The objectives of the system design would be to establish (1) the effects of abrasives, (2) the effect of erosion on pipes and fittings, (3) erosion versus slurry velocities, (4) settling and plugging characteristics, and (5) fouling characteristics caused by polymeric buildup on pipe walls.

NDE methods could be used effectively in such a test facility. For example, ultrasonic as well as radiographic methods could be tested for their effectiveness in detecting erosion and plugging of lines, various NDE techniques could be evaluated, and valuable quantitative data from NDE systems could be obtained to help reach the objectives of the proposed test facilities program, particularly in erosion measurements. 
h. Evaluation of Process Pumps for Cresap Testing, E. J. Miles and E. G. Halleck, Fluor Engineers and Constructors, Inc., Special Report, March 1976 (Ref. 35)

This report discusses the problems that limit the life of liquefaction process pumps, defines a program to test improved systems, and specifies improvements for an acceptable commercial process. The report points out the erosion and rapid wear of internal pump parts and the sealing problems associated with high temperatures and high pressures of the liquefaction process. Severe erosion of impellers is also mentioned. There are possibilities of acoustic monitoring to predict the remaining lifetime of pump components.

i. Evaluation of High Pressure-High Temperature Pressure Vessel End Closures and Flanged Connections, Spccial Report, Fluor Engineers and Constructors, Inc., September 1975, Prepared for $\underline{E R D A}^{36}$

This report studies the various types of pressure vessels, closures, and flanged connections for high-pressure, high-temperature processes in coal-liquefaction plants. Pressures up to $3.5 \mathrm{MPa}(5000 \mathrm{psi})$ and temperatures to $480^{\circ} \mathrm{C}\left(900^{\circ} \mathrm{F}\right)$ are experienced. Highly reliable leak-tight joints are required for safe containment of dangerous fluids. Problems in flanges. have - been experienced in the hydrogenation unit at the Cresap Plant in pre-1970 years. Fluor proposed establishing effective inspection, handling, and assembly methods for flanges and end closures. There is a potential here for application of NDE methods in preservice inspection of critical components and leak-detection systems for in-service application.

j. Evaluation of CSF Process Extractor Pcrformance Improvement for Cresap Testing, Special Report by Fluor Engineers and Constructors, Inc., April 1976, Prepared for ERDA

This report examines possibilities for improving the life of the $\mathrm{CSF}$ process extractor unit in the Cresap pilot plant. Various bearings designs were considered which resulted in a particular bearing concept. There have been repeated bearing failures due to the presence of abrasive slurries. Here, acoustic devices may be useful to monitor the state of wear of the susceptible bearing systems.

k. Evaluation of the Use of Existing Cresap Pilot Plant Vessels for. Development Testing, Special Report, Fluor Engineers and Constructors, Inc., Los Angeles, April 1976, Prepared for ERDA ${ }^{38}$

This report discusses pressure vessels and bins of the Cresap Liquefaction Plant. Coal-feed bins, slurry-mix tanks, the coal-extraction reactor vessel, and the carbonization reactor vessel are discussed, and 
associated problems are examined. Associated with the coal-feed bins are air-leakage and valve-malfunction problems as well as problems with explosion hazards from fine coal dust. There is a need to monitor the oxygen level here as well as the valve leakage.

Slurry-mix tanks have problems because of abrasion and erosion. The extractor pressure vessel is associated with bearing wear and excessive vibrations. There is a need to assess the effects of these vibrations. The Carbonization Reactor Vessel has a need for controlling fluidized-bed level, velocity, and air intake. Hot spots are formed from excessive temperature. Infrared monitoring may be a potential NDE technique for early detection of problem areas. Currently, thermocouples are used and have indicated temperatures in excess of $800^{\circ} \mathrm{C}\left(1500^{\circ} \mathrm{F}\right)$. There has also been local overheating of the Carbonization Vessel bottom cone due to cracking of the refractory lining.

Poor fluidization of the bed with resulting plugging and hot spots can be lessened to a great extent by maintaining adequate fluidizing-gas velocity. Techniques for measuring this flow would be desirable.

1. Evaluation of Heat Exchange for Cresap Testing, E. D. Ellefson, Fluor Engineers and Constructors, Inc., Los Angeles, Report Prepared for ERDA, April 1976 (Ref. 39)

The solid matter in coal slurries can result ultimately in a lowering of the performance of heat exchangers. This results from erosion and corrosion of tubing and general fouling (and possibly plugging) of the lines. Among other parameters needed to design efficient heat exchangers are the erosion-corrosion rates and fouling characteristics of these systems. This report evaluates heat-exchanger designs and recommends a test program.

The recommended test program would provide corrosion-erosion data and fouling characteristics for heat-exchanger tubes. Specific locations are suggested for test coupons in corrosion-erosion studies as part of the general test program at Cresap. Data will have to be obtained as a function of fluid velocity. The needs presented in this report suggest that several NDE methods may be used in such a program to ensure that relevant on-line data are acquired. Ultrasonics can be employed for wall-thinning measurements to monitor corrosion-erosion. Radiography may be used for fouling and plugging characteristics, and acoustic techniques may be employed for slurry velocity measurements.

m. Results of Demonstration of a Reliability Assessment Methodology Using Two Coal Conversion Plant Models, Final Report, June 6, 1975 , Kaman Sciences Corporation, Colorado Springs ${ }^{40}$

This report demonstrates a reliability methodology developed by Kaman Sciences Corporation and its application to two coal-conversion plants: 
the FMC Corporation COED Plant and the HYGAS Plant. Although the data presented are primarily for a gasification plant (HYGAS), the larger failurerate number presented $\left(10^{-2} / \mathrm{h}\right.$ for a hydrogen-plant slurry pump and $10^{-3} / \mathrm{h}$ for a hydrogen compressor) suggests that good on-line NDE apparatus or monitoring equipment will be useful in optimizing the life of critical systems by anticipating costly system failures before they occur. An analysis such as this can point to the critical and least reliable systems.

\section{n. Construction of the SRC Pilot Plant, R and D Report No. 43, Interim No. 9, Pittsburg and Midway Coal Mining Company, Tacoma (Ft. Lewis), Washington ${ }^{41}$}

This report discusses the SRC process and design modifications made in the plant as well as the construction work at various stages. One area discussed in detail is that of the filter section of the mineral-separation unit. The coal solution from the dissolver area still contains undissolved solids, which must be filtered out. The nature of the slurry makes the separation step difficult. The difficulties arise from the fine size of the solids and the high viscosity of the coal-solvent solution.

Pressures of 1.4 MPa (200 psi), and temperatures up to $340^{\circ} \mathrm{C}$ $\left(650^{\circ} \mathrm{F}\right)$ may be required for a successful filtration operation. One of the major problems for the separation unit is to maintain a continuous discharge of solids to atmospheric pressure. This requires that significant leakage to surroundings is avoided since pressure variations can upset the operation of the filter screen. A need appears to be suggested here for a leak monitoring system coupled with proper quality control and periodic checking of the components of this sensitive process.

o. Coal Liquefaction at the Cresap, West Virginia, Pilot Plant, J. A. Phinney, Coal Conversion Plot Plant Symposium, American Institute of Chemical Engineers, Pittsburgh, Pennsylvania, June 2-5, 1974 (Ref. 42)

This paper reviews the significant reeulte of operating the Cresap pilot plant. In addition to problems with pump seals, bearings, line plugging, and filters, the difficulties associated with the compression of hydrogen [20 MPa (3000 psi)] were discussed. Failures occurred in valves and rings. Major problems of the hydrogenation unit were also noted. Here, temperatures to $400^{\circ} \mathrm{C}\left(800^{\circ} \mathrm{F}\right)$ and pressures to $[25 \mathrm{MHa}(3500 \mathrm{psi})]$ are experienced. Pump failure, leakage through piping closures, and failure of pump packing were mentioned. 
p. A Study of the State-of-the-Art of Instrumentation for Process Control and Safety in Large-Scale Coal Gasification, Liquefaction, and Fluidized-bed Combustion Systems, N. M. O'Fallon,

R. A. Beyerlein, W. W. Managan, H. B. Karplus, and

T. P. Mulcahey, ANL-76-4, January 1976 (Ref. 16)

This report discusses the state of the art of instrumentation for process control and safety for coal gasification, liquefaction, and fluidizedbed combustion. Deficiencies are identified for large-scale plants. Areas of need are in measuring mixed-phase mass flow, on-line composition, oil/water interface levels, and reactor-vessel and -wall temperatures. The need of measuring the oil/water interface [at SRC (Ft. Lewis), for example] arises from a step in which oil and water vapors are condensed out of a gas for collection. Knowledge of the interface is important to prevent water passage through an oil trap. The small difference in density and the dirty nature of the mixture make simple optical or nuclear devices inadequate. The authors recommend several techniques for development of level detectors, including acoustical methods and electrical time domain reflectometry.

Another area of concern is hot spots on vessel walls and pipes. Temperature-sensitive paints now used react too slowly and are sensitive to ambient conditions. A combination of radiation pyrometry and thermister strips are suggested for monitoring hot spots.

A third area of interest is mass flow. The development of flow systems including a solid/liquid loop is recommended for evaluation of massflow devices. Acoustic (passive and active), electromagnetic, nuclear, and correlation devices are suggested and discussed for development in mass-flow instrumentation.

q. Argonne National Laboratory Materials Science Division Failure Analysis Reports for Coal Conversion Systems

(1) Synthane Weld Neck Flange Failure: Failure Analysis Report, ANL/MSD/FE-77-2, S. Danyluk and G. M. Dragel, August 1977.

(2) Synthane Gasifier Distributor Cone Thermocouple Sheath (TE-268) Failures: Failure Analysis Report, ANL/MSD/FE77-1, S. Danyluk and G. M. Dragel, August 1977.

(3) EBV Ball-valve Stem Failure--Synthane Coal-gasification Pilot Plant: Failure Analysis Report, ANL/MSD/FE-77-4, S. Danyluk and Cr. M. Dragel, August 19.77 .

Although these failures (all of which shut down the plants) are for coal-gasification systems, they all could occur in liquefaction plants as well. Proper NDE of these critical components could have indicated the potential problem before failure stopped the plant operation. 
In the failure of the weld-neck flange, a leaking crack was discovered in a Type 304 stainless steel weld neck flange that is part of a preheat line. Other nonleaking intergranular cracks were also found at the neck ID. Periodic in-service inspections by ultrasonic techniques (although difficult because of access) could have detected these cracks before they resulted in shutdown.

In the failure of the distributor-cone thermocouple sheath, corrosion cracks initiated at the $O D$ of the sheath material at surface cracks or pits. More careful control over sheath fabrication (Incoloy 800) is advised in this report. Proper application of NDE techniques after fabrication such as eddy-current, optical-radiography, or dye-penetrant methods could significantly reduce the possibility of failure of this critical component.

In the ball-valve failure, the valve stem fractured completely. Failure was attributed to the presence of preexistent surface defects. More stringent quality control over the preparation of the valve is suggested in this report. Again, various techniques could be implemented to detect flaws before the valve is put into service. This includes radiography, ultrasonic, visual, dye-penetrant, and eddy-current techniques. The valve stem could also have been checked during an in-service inspection, as the valve stem was accessible for possibly ultrasonic, eddy-current, visual, or dye-penetrant testing.

Other selected reports and papers of related interest are Refs. 44-49. 


\section{APPENDIX B}

\section{Contact Summary}

\section{Individuals}

Many individuals from both government and industrial organizations have been contacted to assist in identifying liquefaction-plant problems that may be minimized by effective application of NDE techniques.

Individuals contacted are listed below, followed by a summary incorporating their comments in a discussion of problems with potential for NDE applications.

a. Energy Research and Development Administration

(1) Mr. Harold Fisher, Program Manager for the SRC Plant, Tacoma (Ft. Lewis), Washington

(2) Mr. George Dick, Program Manager CSF, Cresap, West Virginia

b. Hydrocarbon Research Inc. (H-coal Process), Trenton, New Jersey

(1) Dr. Paul Kydd, Vice President of Technology

(2) Mr. Carmine Battista, Project Manager

c. Ralph M. Parsons Corp., Pasadena, California

(1) Mr. Walter Lockmann, Chief Materials Application Engineer

d. Pittsburg and Midway Coal Mining Company (SRC), Tacoma

(Ft. Lewis), Washington

(1) Mr. Joseph Nayler, Senior Process Engineer

(2) Mr. Dennis Canfield, Metallurgical Engineer

(3) Mr. Lloyd Furler, General Foreman; Inspection Engineering

e. Fluor Engineers and Constructors, Santa Anna, Califurnia

(1) Mr. Harold Finch, Plant Manager, Cresap Plant

(2) Mr. Fred G. Brooks, Test Program Manager, Cresap Plant

(3) Mr. Arch Wilder, Mechanical Engineer Superintendent, Cresap Plant

(4) Dr. William Hong, Senior Corrosion Engineer

(5) Mr. John Wexler, NDT Engineer

(6) Mr. Pete Michalsky 
f. Argonne National Laboratory, Argonne, Illinois

(1) Dr. William Ellingson, Project Leader, Synthetic Fuels Program, Materials Science Division

(2) Dr. Nancy O'Fallon, Project Leader, Coal Process Instrumentation Development, Applied Physics Division

(3) Dr. Steve Danyluk, Metallurgist, Materials Science Division

(4) Dr. William Shack, Project Leader, Corrosion Studies Program, Materials Science Division

A unique problem in coal-liquefaction plants is the high percentage of solids in the process streams, higher than even that present in coal-gasification plants. As a result, severe problems may arise due to the erosive/corrusive nature of these plants. Erosion/corrosion problems are the main area in which NDE may be effective and contributions to reducing problems in liquefaction plants may be made by NDE techniques. Although corrosion is a severe problem for coal-liquefaction plants, similar problems have been handled previously in chemical plants. The severity of the erosion problems, however, have not been handled routinely before.

The problems of erosive process streams become important, as they can cause severe thinning of transfer lines, elbows, and tees, and erosion of pumps, including impellers and casings. At present in existing pilot plants (SRC and Cresap, for example), some ultrasonic monitoring of critical lines is carried out by hand-held ultrasonic probes. However, these measurements cannot be carried out at system operating temperatures, which may reach $850^{\circ} \mathrm{F}$ $\left(450^{\circ} \mathrm{C}\right)$. Development of high-temperature ultrasonic techniques for monitoring critical system components while a plant is in operation could significantly im prove the value gained from current in-service NDE evaluation. Sorne of the current NDE efforts at Argonne National Laboratory ${ }^{2}$ are in fact aimed at developing in-service ultrasonic, infrared, and radiographic means for detection of erosion in critical process lines. As previously mentioned, valves and pumps are subject to severe erosion. High-pressure letdown valves $\{[10$ to $1 \mathrm{MPa}$ (1500 to $150 \mathrm{psi}$ )] in two stages at the SRC Plant, [30 to $0.2 \mathrm{MPa}$ (4000 to $25 \mathrm{psi}$ )] at the Cresap facility may have a useful life of less than 60 days. In-service inspection of letdown and slurry service valves may effectively increase their useful life by monitoring the erosion of critical elements.

At the Cresap test facility, a bypass line is to be installed as a test facility to obtain data on erosion. Effective use of NDE techniques (ultrasonic, acoustic emission, and radiographic, for example) may provide real-time information on erosion effects (localized and general) and process-stream flow patterns in such facilities.

In addition to transfer lines, pumps, and valves, erosion may be troublesome in other critical areas. One example is in the experience at Cresap. A 
shaft in an extractor, employed after coal and solvent are mixed at $430^{\circ} \mathrm{C}$ $\left(825^{\circ} \mathrm{F}\right)$, and $3.5 \mathrm{MPa}(500 \mathrm{psi})$, was severely eroded near the shaft bearings. A new design was required. It uses a flexible shaft that may relieve the erosion problem. This new design, however, may require a vibration-detection system to monitor the shaft for excessive vibration. Two examples of corrosion problems can be found at the SRC Plant (Tacoma). Stress-corrosion cracking can occur (sulfidation) in the main pressure vessel. Corrosion has also been a problem in the SRC distillation column, particularly with carbonsteel trays.

In-service NDE methods (ultrasonic, infrared, and radiographic) may be useful for detecting such corrosion problems before they become serious. There are potential problems in liquefaction plants that may lead to detectable hot spots. Hot spots may be detectable on liquid flow dissolver vessels (SRC) if localized erosion/corrosion causes excessive wall thinning. Heat-tracing tape is currently used for monitoring, but the application of infrared (IR) technology may significantly improve the monitoring of hot spots. IR methods may also be used to check bearings as they heat up before failure. In the Cresap Plant, burners have refractory linings. If cracked, they leak and heat up the outside burner. IR monitoring here may provide valuable data to monitor these components.

Electrical switch gear could also benefit from IR monitoring, as hot spots may be evident in bad circuit components. Prefailure data for electrical systems may be critical, as an electrical failure could result in a total plant shutdown. Regular IR monitoring may anticipate these problems and give advance warning.

Another potential problem is leaks. Leaks of flammable liquids or explosive gases around flanges and seals, for example, must be detected and eliminated because of the fire hazard. OSHA may make standards even tougher than they are now. In-service methods for detection may include acoustic techniques as well as conventional optical (UV and visible) and chemical methods for detecting smoke and flammable and explosive mixtures.

In addition to the previously discussed problem areas, another is the plugging of process streams. Often, knowledge of the location of a plug in a line can save considerable time and effort in replacing and cleaning plug lines. Various techniques discussed in later sections may be used to localize the point of plugging in process streams.

Another area of specific concern is in the Synthoil Process Development Unit. Baseline data (ultrasonic and $\mathrm{X}$ ray) on wall thickness in critical areas should be taken before startup. In addition, there is a point at which hydrogen is mixed with a paste at a $\mathrm{T}$ joint. This occurs just before the reactor feed heater. This is a critical point in the process flow and is particularly vulnerable to erosion. Monitoring of this area is extremely important. 
2. Organizations

Two coal-liquefaction plants were visited to obtain on-site information on current NDE methods being used in the field and to help establish the potential for applying additional NDE to plant problem areas.

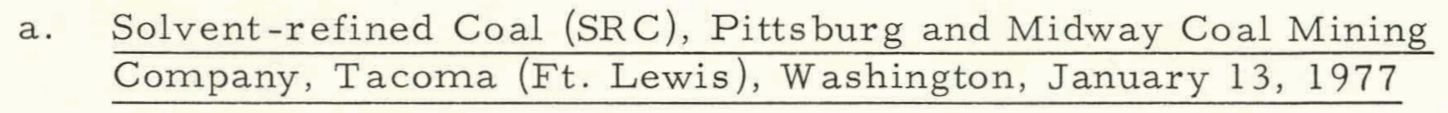

This $50-t / d a y$ SRC Plant is the largest operating facility for liquefaction in the United States. A photograph of the plant is shown in Fig. 1. From a plant tour and discussions with plant personnel, several specific problem areas were identified where NDE is currently employed or is potentially useful.

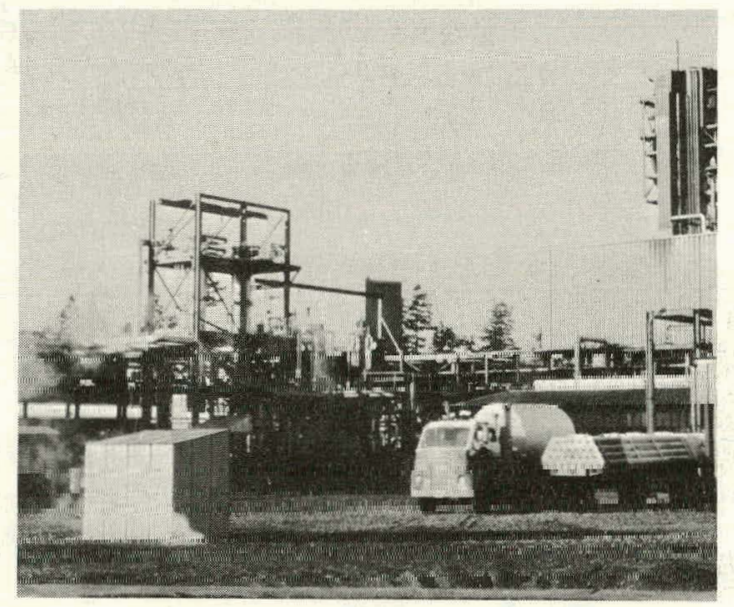

Fig. 1

SRC Plant, Tacoma (Ft. Lewis), Washington. Neg. No. MSD-61135.

(1) Erosion/Corrosion. As previuusly rrentioned, erosion/corrosion problems are a primary concern in the coal-liquefaction process. There are many areas, specitically piping, in which an ultrasonic thickness gaugc is used to monitor the thinning of the numerous critical pipe areas. One example shown in Fig. 2 was a welded pipe (about $7.5 \mathrm{~cm}$ in diameter) where the root bead dis turbs the slurry flow (this occurs before the preheater) and the resulting vortexes severely erode the pipe just beyond the weld. This area is monitored

Fig. 2

Welded Pipe (Stainless Steel) Where Erosion of Pipe Is a Severe Problem in SRC Plant. Currently, thicknesses of ultrasonic pipe walls are measured with hand-held probes during shutdown periods. Neg. No. MSD-64436.

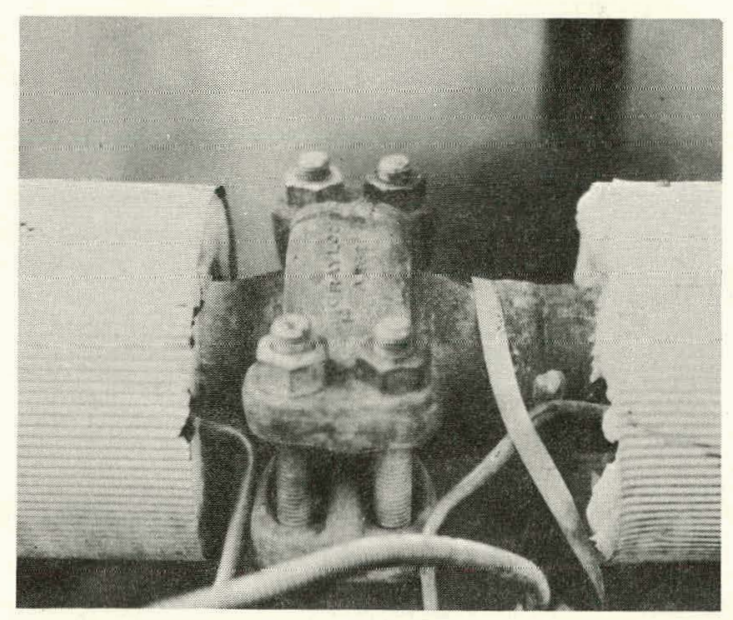


during shutdown, but cannot be monitored during service because of the elevated temperature. Two other examples of severe erosion are shown in Figs. 3 and 4. Figure 3 shows the erosion of a carbon-steel discharge pipe, and Fig. 4 shows the erosion of another discharge pipe of a filter feed-surge recirculation pump.

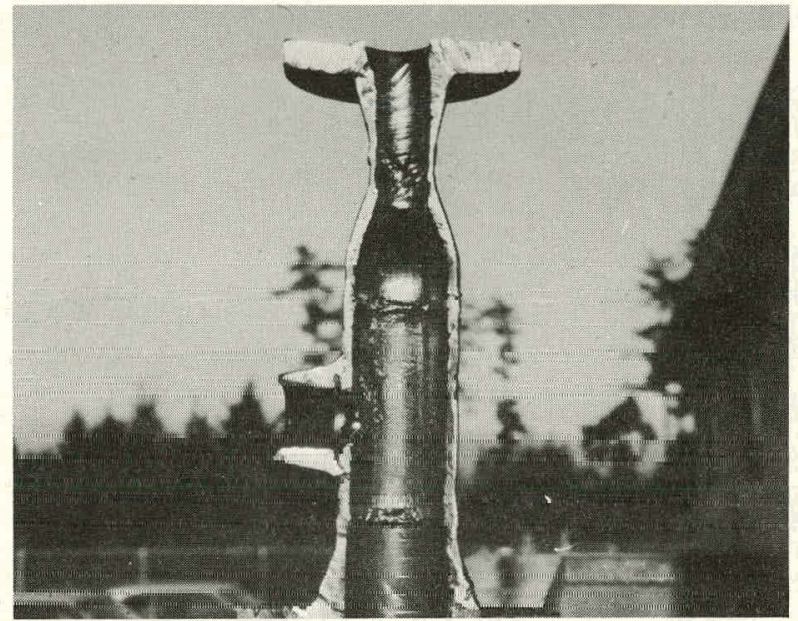

Fig. 3. Carbon-steel Discharge Pipe, Showing Erosion at SRC Plant. Neg. No. MSD-64437.

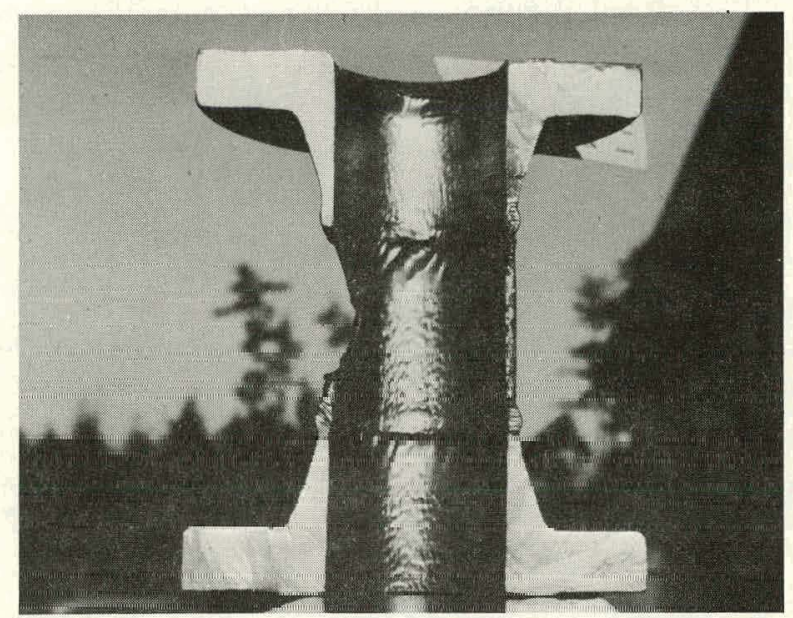

Fig. 4. Discharge Pipe of a Filter Feed-surge Recirculation Pump, Showing Erosion at SRC Plant. Neg. No. MSD-64438.

Another area of concern is the heater coil of the preheater, which had shown indication of severe erosion in the initial stages of operation. Although this erosion has not progressed beyond the early stages (possibly due to buildup of a protective layer), there is still concern. The preheater is seen in Fig. 5 and the heater coil in Fig. 6.

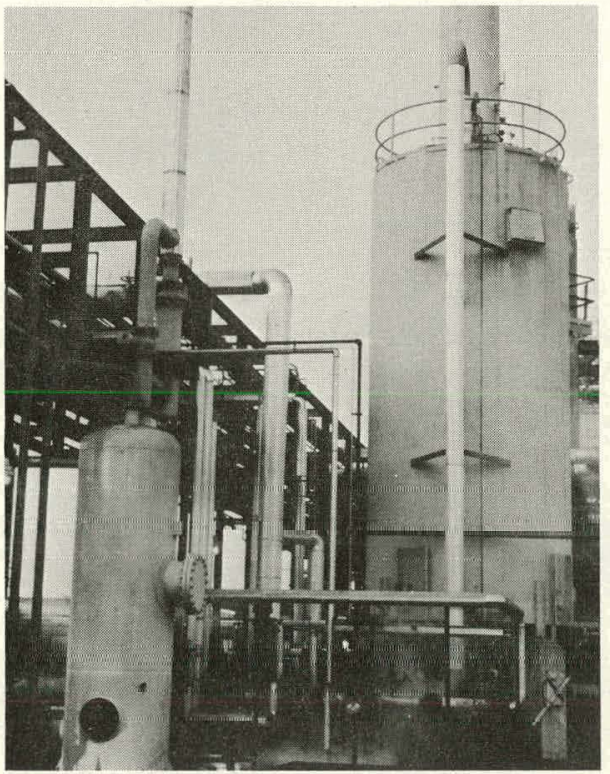

Fig. 5. Preheater at SRC. Plant, Tacoma (Ft. Lewis), Washington. Neg. No. MSD-64439.

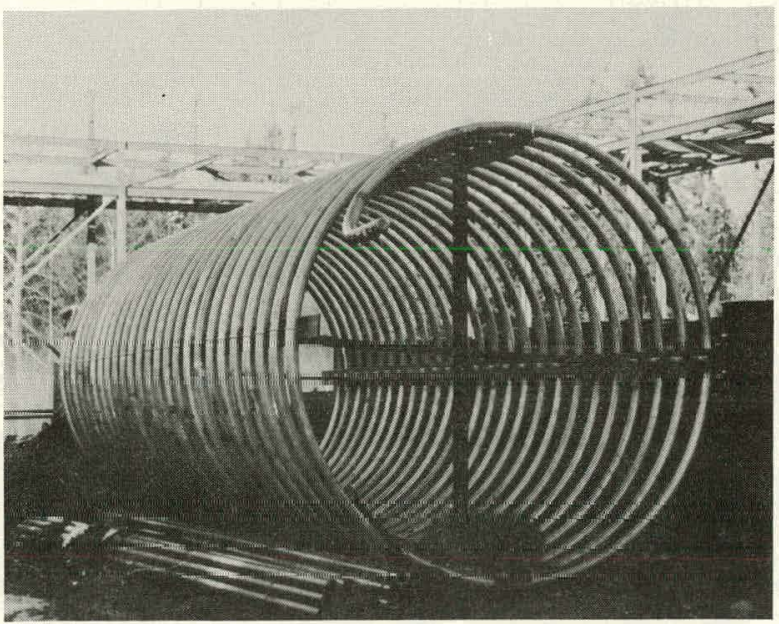

Fig. 6. Preheater Heating Coil at SRC Plant. Neg. No. MSD-64440. 
About 30 heat exchangers are uscd in the plant, and erosion in the tubes is a problem. A method for inspecting the tubes might be in order. One heat-exchanger tube, for example, was completely eroded away.

Slurry pumps are troublesome and have a rather short life. There might be a need for acoustic monitoring of these pumps to identify early stages of wear of the bearings. Figure 7 is a photograph of these pumps.

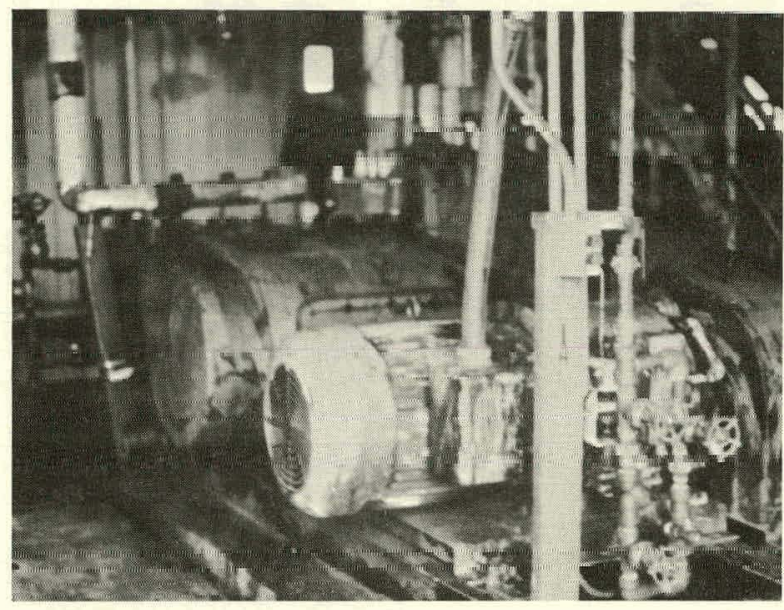

Fig. 7. Slurry Pump at SRC Plant. Neg. No. MSD-64441.

Lelduwn valves are a severe problem area and have a life of only about 2 weeks to a month. Armustir. muniluring of these valves mingl be useful to indicate the statcs of wcar in these valves. Acoustic monitoring may also be valuable if acoustic signals could te currelaled to slurry flow rates. Figure 8 shows one of the se valves.

\section{(2) Other Areas of Potential NDE Applications}

(a) There is a need to monitor a water-oil level in one of the processing tanks. This could possibly be done via acoustics. A marginally successful method taking advantage of the difference in dielectric properties of water and oil is currently being used.

(b) Thermal-profile data would be valuable dissolver vessels (see Fig. 9). Infrared devices might be employed to obtain that information.

(c) Stress-corrosion cracking is a general problem for the fractionation columns (Fig. 10), and any techniques to aid in detection of cracks would be us eful.

(d) Plugging of lines (usually when system is down) is a constant problem. A method to accurately locate the plugs would save considerable time over the sometimes hit-and-miss techniques used now. In one case, a complete system had to be dismantled as the plug location could not be determined.

b. Hydrocarbon Research Incorporated, Process Development Unit, Trenton, New Jersey, January 8, 1977

This $3-t /$ day process development unit, whose facility is shown in Fig. 11, has been relatively free of problems. Nevertheless, there has been one pipe failure due to erosion, and there are potential problems for the scaledup facility, a pilot plant to be built in Catlettsburg, Kentucky. 


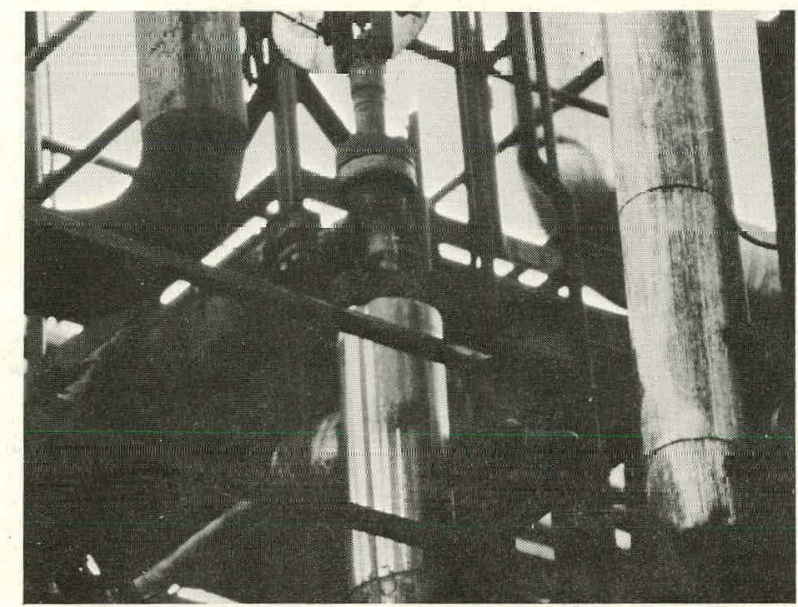

Fig. 8. Letdown Valve at SRC Plant. Neg. No. MSD-64442.

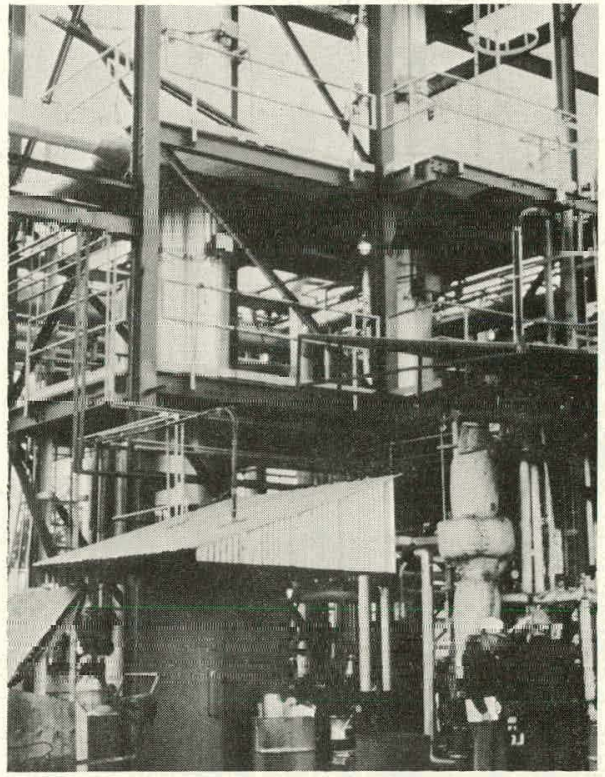

Fig. 9. Dissolver Vessel at SRC Plant. Neg. No. MSD-64443.

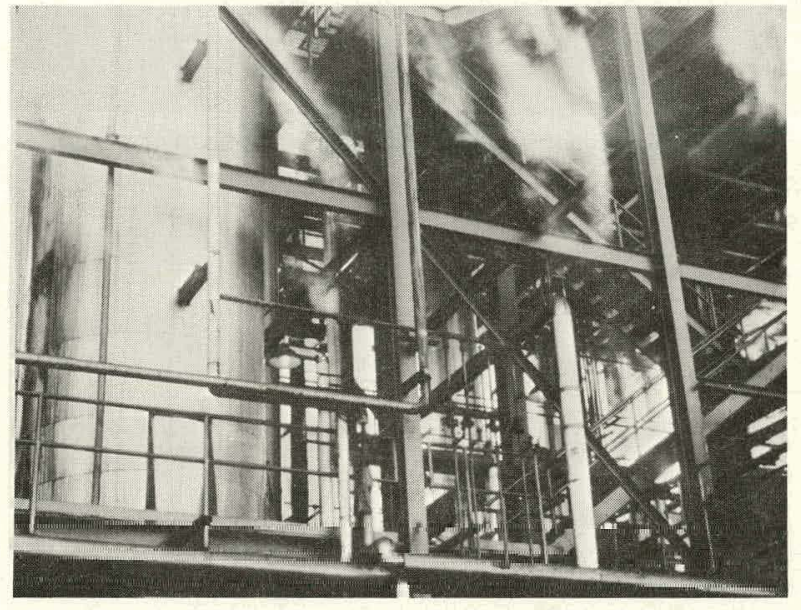

Fig. 10. Fractionation Columns at SRC Plant. Neg. No. MSD-64444.

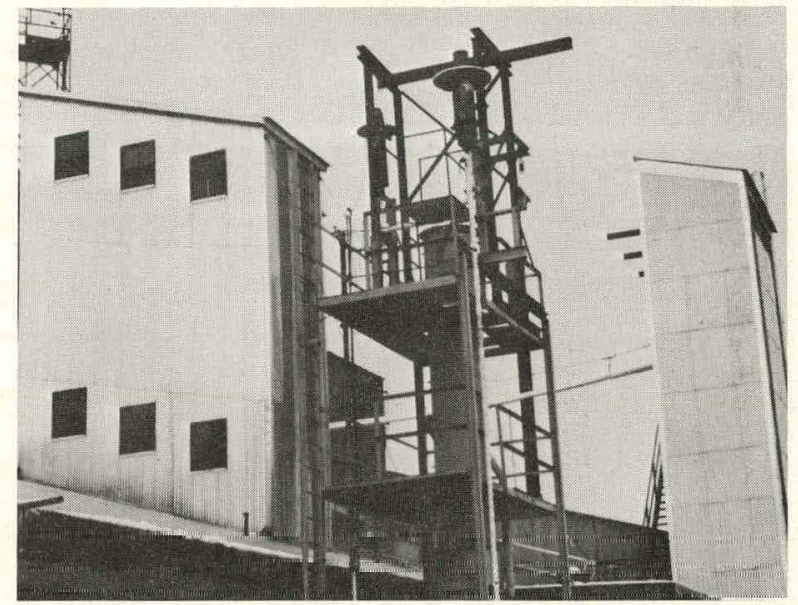

Fig. 11. HRI Process Development Unit, Trenton, New Jersey. Neg. No. MSD-64445.

The pipe failure, due to erosion, occurred in the reactor liquideffluent line (1/2-in. Schedule 160, Type 347 stainless pipe). This line is located after the letdown valve and upstream from the hot atmospheric separator. The erosion occurred in the pipe where there was only a slight bend. No problems occurred in areas with much sharper bends. In general, erosion is not a problem now, except in the letdown valves. The valves are replaced periodically as needed. Hydroclones have experienced problems when metal liners were used, but now that ceramic liners are employed, there are few problems. Some plugging has occurred in separator overhead stream lines. (Plugging is by ammonium chloride deposits.) It would be desirable if these plugs could be detected by some nondestructive technique. 
Nondestructive examinations have been carried out on the process development unit. Welds have been checked via dye penetrant, ultrasonic angle beam (1/2 in., $\left.2.25 \mathrm{MHz}, 45^{\circ}\right)$ and radiography $\left[110-\mathrm{Ci}\left(4.07 \times 10^{12}-\mathrm{Bq}\right)\right.$ source and $160-\mathrm{kV}$ X-ray tube]. Good data could not be obtained from nozzle welds. However, erosion was looked for by ultrasonic thickness measurements in the reactor vessel (Type 347 stainless steel) and in accompanying piping. Essentially no erosion has been detected after a number of years of operation.

Minor problems have been associated with small fires resulting from leaks at seals and flanges. An ultraviolet detection system is in operation to sense the fires. A smoke-detection system might also be useful.

\section{Areas of Potential NDE Application}

a. Wall-thickness measurements of reactor vessel and piping. Although no significant erosion has been noticed, the previously mentioned failure of the slurry line indicates a need for erosion-monitoring measurements.

b. Acoustic monitoring of pumps in critical areas to detect early failing of bearings, ctc.

c. Plugging of lines. Here, methods such as X ray, ultrasonic, and infrared might be used to detect plugs.

d. Measuring pressure in reactor vessels. This parameter is critical, and present pressure taps are expensive and their use is time consuming.

Potential problems to be encountered in scaling up to $\mathrm{H}$-coal pilnt plants are:

a. Erosion problems may become more severe. Thus monitoring may be more important.

b. Detecting the catalyst level in the process development unit will he more difficult than it is now. Presently, in the process development unit, a nuclear density gauge is used to monitor this level. The pilot-plant reactor vessel will be much bigger, however, and it is not clear that the present technique will be practical. The system cannot run without the catalyst level being known. 


\section{ACKNOW LEDGMENTS}

I wish to express my gratitude to W. A. Ellingson and K. J. Reimann of Argonne National Laboratory and all other personnel referred to in this report for providing significant information for the survey. I also wish to thank Marjorie Wilson for assistance in the literature search and the Pittsburg and Midway Coal Mining Company (SRC) and Hydrocarbon Research, Inc. ( $\mathrm{H}-\mathrm{Coal})$, for allowing the site visits and providing staff for the plant tours.

\section{REFERENCES}

1. Coal Liquefaction Design Practices Manual, Electric Power Research Institute (EPRI) Report AF-199 (Project 409-1), Fluor Engineers and Constructors, Inc., (July 1976).

2. G. C. Stanton and W. A. Ellingson, System for UZtrasonic Monitoring of Pipe Wall Thinning in Coal Gasifiers, Mat. Eval. 34(4), 46 (1977).

3. R. E. Beissner, Electromagnetic-Acoustic Transducers, A Survey of the State of the Art, NTIAC-76-1 (Jan 1976).

4. E. R. Dobbs and J. D. Llewellyn, Generation of ULtrasonic Waves Without Using a Transducer, Non-Destr. Test. 4(1), 49 (1971).

5. T. L. Szabo and H. M. Frost, SAW EZectromagnetic Transducer Design for Nondestructive Evaluation Applications, IEEE Trans. Sonics Ultrason. $S U-23(5), 323$ (1976).

6. D. M. Wilson, P. T. Cole, and K. R. Whittington, "The Development of an Electromagnetic-Acoustic System for NDT of a Steel Bar at Elevated Temperature," Eighth World Conf. Nondestructive Testing, Cannes, France, Paper 1A5 (Sept 6-9, 1976).

7. 0. R. Gericke, "Ultrasonic Spectroscopy," Research Techniques in Nondestructive Testing, edited by R. S. Sharpe, Academic Press, New York, p. 31 (1970).

8. M. DeBilly, F. Cohen-Tenoudji, A. Jungman, and G. J. Quentin, The Possibility of Assigning a Signature to Rough Surfaces Using ULtrasonic Rark.srattering Diagroms, IEEE Trans, Sonics Ultrason. SU-23(5) (1976).

9. R. J. Sawley and P. H. White, The Influence of Pressure Recovery on the Deve Zopment of Gas Valve Noise Descriptions, Adv. Instrum. 29(4), Paper \#834 (1974).

10. Materials Science Division Coal Technology Tenth Quarterly Report, January-March 1977, ANL-77-41.

11. C. R. Sparks and J. C. Wackel, Quantitative Signature Analysis for Onstream Diagnosis of Machine Response, Mat. Eval. 31(4), 53 (1973).

12. R. B. Socky, "Signature Analysis--A Materials Reliability Testing Technique," Symp. On-stream Nondestructive Examination of Rotating Machinery, 1972 Fall ASNT Conference, Cleveland, Ohio (Oct 16-19, 1972).

13. K. A. Smith, "Mechanical Signature Analysis of Rotating Machinery," Symp. On-streom Nondestructive Excomination of Rotating Machinery, 1972 Fall ASNT Conference, Cleveland, Ohio (Oct 16-19, 1972). 
14. Workshop on Materials Problems and Research Opportunities in Coal Conversion, The Ohio State University, Columbus, Ohio (Apr 16-18, 1974).

15. D. S. Kupperman and K. J. Reimann, Microstructural Effects and Signalenhancement Techniques in ULtrasonic Excomination of Stainless Steel, ANL-76-115 (Sept 1976).

16. N. M. O'Fallon, R. A. Beyerlein, W. W. Managan, H. B. Karplus, and T. P. Mulcahey, A Study of the State-of-the-Art of Instrumentation for Process Control and Safety in Large-Scale Coal Gasification, Liquefaction, and Fluidized-Bed Combustion Systems, ANL-76-4 (Jan 1976).

17. K. J. Longua, G. K. Whitham, and K. J. Reimann, In-service Inspection of EBR-II Evaporator EV-702, ANL-77-46 (June 1977).

18. D. S. Kupperman, C. L. Johnson, and W. A. Ellingson, "Evaluation of Ultrasonic Techniques for Detection of Stress Corrosion Cracks in Stainless Steel Piping," ASNT FalZ Conference, Houston, Texas (Sept 1976).

19. P. II. Iluttun and J. R. Skorpik, scientific Research to Develop a Digital Memory Acoustic Emission Zone Monitor/Recorder for BWR Pipo Cracking Detection, Battelle Pacific Northwest Laboratories Report to Electric Power Research Institute, EPRI No. RP-505, BNW No. 2311202511 (1977).

20. R. B. Thompson and A. G. Evans, Goals and Objectives of Quantitive Ultrasonics, IEEE Trans. Sonics U1trason. SU-23(5) (1976).

21. IEEE Trans. Sonics U1trason. SU-23(5) (1976).

22. F. L. Becker, A. J. Boland, J. C. Crowe, V. I. Crow, T. J. Davis, B. P. Hildebrand, and G. J. Pasakony, Development of on Ultrasonic Imaging System for the Inspection of Nuclear Reactor Pressure Vessels, 2nd progress report by Battelle Pacific Northwest Laboratories for the Elecrrlc Power Research Institute, Palo Alto, Calif., EPRI Contract No. RP-606-1, BNW No. 231120558 (Jan 1977).

23. A. E. Holt, "Acoustical Holographic Characterization of Defects in Pressure Vessel Materials," Third Int. Conf. Pressure Vessel. Technolngy, Tokyo, Japan (Apr 19-22, 1977).

24. D. O. Harris and H. L. Dunegan, Verification of Structural Integrity of Pressure Vessels by Acoustic Emission and Periodic Proof Testing, STP-515, American Society for Testing and Materials (1972).

25. A. H. Wehrmeister, Acoustic Emission Monitoring of Multi-Pass SubmergedAre Welding, Mat. Eval. 35(6), 45 (1977).

26. R. Shanker, A. N. Mucciardi, D. Cleveland, W. E. Lawrie, and H. L. Reeves, Adaptive Nonlinear Signal Processing for Characterization of ULtrasonic NDE Waveforms, Adaptronics, Inc., and Babcock \& Wilcox report for Air Furce Materials Laboratory, Wright-Patterson Air Force Base, Ohio, AFML-TR-76-44 (Apr 1976).

27. J. H. Walter, "Automated Ultrasonic Examination of Light Water Reactor Systems," in Periodic Inspection of Pressurized Components Conferance Proceedings, Institution of Mechanical Engineers, Mechanical Engineering Publications, Limited, New York (1974).

28. D. Prine, NDT of Welds by Acoustic Emission, Dunegan/Endevco, San Juan, Calif. Technical Report DE 73-X. 
29. D. Prine, "Inspection of Nuclear Reactor Welding by Acoustic Emission," 5th Annual Water Reactor Safety Research Information Meeting, Gaithersburg, Md. (Sept 28, 1976).

30. Materials Technology in the Near Term Energy Program, National Academy of Science, Washington, D.C. (1974).

31. H. E. Frankel, "Reliability Problems in Coal Gasification and Liquefaction," Mechanical Failures Prevention Group Symposium on Prevention of Failures in Coal Conversion Systems, (Apr 21-23, 1976). Battelle-Columbus Laboratory, Columbus, Ohio.

32. W. Hong and J. Richards, "Overview of Material Problems in Coal Liquefaction Pilot Plant," NACE National Meeting, Houston, Texas (Mar 26, 1976).

33. Materials Considerations in Coal Liquefaction, J. B. O'Hara, W. J. Lochmann, and N. E. Jentz, Met. Prog. (Nov 1976).

34. Pipe System Erosion and Hydraulics Analysis at the Cresap Pizot Plant, Fluor Engineers and Constructors, Inc., FE-1517-32 (May 1976).

35. E. J. Miles and E. G. Halleck, Evaluation of Process Pumps for Cresap Testing, Fluor Engineers and Constructors, Inc., Special Report, FE-1517-31 (Mar 1976).

36. Evaluation of High Pressure-High Temperature Pressure Vessel End Closures and Flanged Connections, Fluor Engineers and Constructors, Inc., Special Report, FE-1517-22 (Sept 1975).

37. Evaluation of CSF Process Extractor Performance Improvement for Cresap Testing, Fluor Engineers and Constructors, Inc., Special Report, FE-1517-33 (Apr 1976).

38. Evaluation of the Use of Existing Cresap Pilot Plant Vessels for Development Testing, Fluor Engineers and Constructors, Inc., Special Report, FE-1517-26 (Apr 1976).

39. E. D. Ellefson, Evaluation of Heat Exchange for Cresap Testing, Fluor Engineers and Constructors, Inc., Special Report, FE-1517-28 (Apr 1976).

40. Results of Demonstration of a Reliability Assessment Methodology Using Two Coal Conversion Plant Models: Final Report, Kaman Sciences Corp., Colorado Springs, FE-1788-T-1 (June 6, 1975).

41. Construction of the SRC PiZot Plant, R and D Report No. 43, Interim No. 9, Pittsburg and Midway Coal Mining Company, Tacoma (Ft. Lewis), Washington.

42. J. A. Phinney, "Coal Liquefaction at the Cresap, West Virginia, Pilot Plant," Coal Conversion Pilot Plant Symposizm, American Institute of Chemical Engineers, Pittsburgh, Pa. (June 2-5, 1974).

43. Argonne National Laboratory Materials Science Division Failure Analysis Reports for Coal-conversion Systems: S. Danyluk and G. M. Drage1, Synthone Gasifier Distributor Cone Thermocouple Sheath (TE-268) Failure: Failure Analysis Report, ANL/MSD/FE-77-1 (Aug 1977); S. Danyluk and S. M. Dragel, Synthane Weld Neck Flange Failure: Failure Analysis Report, ANL/MSD/FE-77-2 (Aug 1977); S. Danyluk and S. M. Dragel, EBV BalZ-valve Stem Failure--Synthone Coal-gasification Pilot Plant: Failure Analysis Report, ANL/MSD/FE-77-4 (Aug 1977). 
44. A. J. MacNab, "The Materials/Design Interface in Coal Conversion Technology," Workshop on Materials Problems and Research Opportunities in Coal Conversion, The Ohio State University, Columbus, Ohio (Apr 16-18, 1974).

45. G. C. Stanton and W. A. Ellingson, System for UZtrasonic Monitoring of Pipe-wall Thinning in Coal Gasifiers, Mat. Eval. 35(4), 46-51 (Apr 1977).

46. H. E. Franke1, G. A. Mills, and W. T. Bakker, "Materials Problems (Real and Imagined) in Coal Gasification Plants," Symp. Critical Materials Problems in Energy Production, sponsored by Air Force Weapons Laboratory and New Mexico Institute of Technology (Aug 1976).

47. W. T. Bakker, "Ceramics in Coal Utilization Systems," Workshop on Ceramics for Energy Applications, Columbus, Ohio (Nov 24-25, 1975).

48. H. F. Keller, Carrier Corp., Carrier Parkway, Syracuse, N.Y., private communication.

49. "Status of Coal Liquefaction Technology," gth Inlersociety Energy conversion tingineering l'onference Hroceedings, San Francisco, Cajifornia, pp. 1020-1034 (Aug 26-30, 1974). 
Internal:

E. G. Pewitt

J. Fischer

L. Burris

B. R. T. Frost

A. A. Jonke

R. W. Weeks

L. G. LeSage

F. A. Nichols

M. F. Adams (2)

G. S. Rosenberg.

T. M. Mulcahy

D. R. Diercks

D. S. Kupperman (10)

T. F. Kassner

K. J. Longua

R. B. Poeppel

G. K. Witham

K. J. Reimann

A. B. Krisciunas

W. A. Ellingson ANL Contract File

W. J. Shack

ANL Libraries (5)

J. Y. Park TIS Files (6)

\section{External:}

ERDA-TIC, for distribution per UC-90d (285)

Manager, Chicago Operations Office

Chief, Chicago Patent Group

President, Argonne Universities Association

Materials Science Division Review Committee:

G. S. Ansell, Rensselaer Polytechnic Inst.

R. W. Balluffi, Cornell U.

S. Doniach, Stanford U.

H. L. Falkenberry, Tennessee Valley Authority

C. Laird, U. Pennsylvania

D. Lazarus, U. Illinois

M. T. Simnad, General Atomic

A. R. C. Westwood, Martin Marietta Labs. 